Vivi Lena Andersen er mag.art. i forhistorisk arkæologi fra Københavns Universitet. Siden 2001 ansat på Københavns Museum, fra 2008 som museumsinspektør. Vivi Lena Andersen underviser desuden i nyere tids arkæologi og garbage archaeology ved forhistorisk arkæologi, Københavns Universitet og har ledet flere lossepladsudgravninger i Frederiksstaden. Koordinator for udstillingerne "Affaldets stemmer" i 2008 og "SKRALD!" i 2011/2012 ved Københavns Museum.

\title{
STADENS UREENLIGHED
}

\section{Lossepladskultur i 1700-tallets København}

Larmen fra den flere tons tunge gravemaskine er øredøvende, og al menneskelig kommunikation foregår via råb, håndtegn og viftende arme. Gentagne vink betyder stop, mens en rullende bevægelse med hånden betyder grav videre. Og videre graver maskinen og løfter endnu et læs. Stanken fra det opgravede er lige så indtrængende som larmen, men man vender sig overraskende hurtig til begge gener.

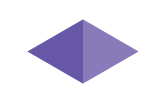

$\AA$ ret er 2003, og stedet er Esplanaden 50, A.P. Møller-Mærsks hovedsæde i København. Adressens placering i den nordøstlige del af Frederiksstaden, tæt ved kysten nord for det indre København, betyder, at man rammer en del af en losseplads fra 1700-tallet, når en skovl stikkes dybt nok ned. På denne matrikel udgravede arkæologer fra Københavns Museum i 2003 og 2004 tre meter tykke affaldslag indeholdende en mangfoldighed af velbevarede objekter og fækalier fra 1700-tallets københavnere; mennesker såvel som dyr. De færreste, der bor i denne bydel i dag, ved, at der neden under asfalten og de prominente palæer gemmer sig en 300 år gammel losseplads. Det er en funktion og en periode af områdets fortid, som yderst sjældent nævnes i den almene historiefortælling.

Udgravningen af lossepladsen under Esplanaden 50 viste sig at være starten på en ny æra for det arkæologiske arbejde og satsningsområder ved Københavns Museum, som i de seneste 10 år har opprioriteret udgravninger og forskning inden for nyere tids arkæologi og affaldsarkæologi. Udgravningen vakte også national og international interesse. Det skyldtes dels, at genstandsmaterialet traditionelt 
set blev vurderet til at være for ungt til, at det kunne have arkæologisk interesse i Danmark og dels, at det var usædvanligt at foretage en arkæologisk udgravning af en losseplads. ${ }^{1}$

Det er sidenhen blevet til adskillige udgravninger på lossepladsområdet under Frederiksstaden, og det var derfor naturligt, at denne, nu velundersøgte, losseplads skulle indgå i et forskningsprojekt om storbyens affald, som denne artikel er en del af.

I begyndelsen af 2011 fik Københavns Museum bevilliget midler fra Kulturstyrelsen til at gennemføre det tværfaglige forskningsprojekt "Storbyens Spild undersøgelser i den moderne velfærdskulturs affaldshåndteringer”. Projektet bestod af fem individuelle undersøgelser, som ved hjælp af etnologiske, historiske og arkæologiske metoder studerede, hvordan byen i praksis håndterer og har håndteret forbrugets efterliv, i form af affaldet, fra 1700-tallet og frem, og hvordan dette har materialiseret sig. Undersøgelserne dannede desuden baggrundsmateriale for museets særudstilling om skrald, der åbnede i oktober 2011. Denne artikel omhandler den ene af de fem undersøgelser, som skildrer en af de første lossepladser i enevældens København og giver et sjældent indblik i en skjult lokalitet i det urbane rum.

I mit magisterkonferensspeciale fra 2007 analyserede jeg 1156 af de fundne sko og skodele fra lossepladsen under Esplanaden 50 med fokus på genstandstypen og dennes udsagnsværdi. ${ }^{2}$ Desuden viste studiet på nogle punkter uoverensstemmelser mellem det arkæologiske, historiske, kartografiske, ikonografiske og etnologiske kildemateriale samt åbnede op for flere spørgsmål om selve konteksten, lossepladsen - herunder dens funktionsperiode. Hensigten med denne artikel er med en kulturhistorisk indgangsvinkel at genoplive en ofte overset lokalitet i byrummet, samt at sammenholde de forskellige typer af kildemateriale om lokaliteten og endelig at reflektere over, hvilke perspektiver et fortsat arbejde med dette område synes at rumme.

Med lossepladsen opstod et helt nyt samfundsfænomen i håndteringen af affaldet og et nyt rum i det urbane landskab blev dannet, men hvad viser det fundne affald om affaldskulturen i enevældens København? Hvordan så lossepladsen ud? Hvornår opstod behovet for lossepladsen under Frederiksstaden?

Undersøgelsens metodiske udgangspunkt er den arkæologiske i form af de registrerede udgravninger, de arkæologiske tilsyn og de dertil hørende fund og anlæg. De relevante udgravningers beretninger, tegninger, fotos, fundrapporter, genstandsregistreringen, sagsregistreringen, det topografiske arkiv og de naturvidenskabelige- og geotekniske rapporter ved Københavns Museum udgør fundamentet for undersøgelsen. Udgravningen på Esplanaden 50 er den mest omfangs- 
rige og veldokumenterede af udgravningerne, og den spiller derfor en væsentlig rolle i denne undersøgelse i samspil med de øvrige udgravninger. For at besvare ovennævnte spørgsmål inddrages både geotekniske, skriftlige, kartografiske, ikonografiske og naturvidenskabelige kilder. Dermed opnås et mere nuanceret indblik i en af enevældens tidlige lossepladser og den datidige affaldshåndtering. De forskellige kildegrupper giver både mulighed for at supplere det arkæologiske materiale og desuden for at reflektere over kildegruppernes udsagn i forhold til hinanden. ${ }^{3}$

I Gyldendals encyklopædi beskrives losseplads som ”et deponi, en plads hvor affald henlægges i større mængder”. Med denne definition har fænomenet angiveligt eksisteret, så længe mennesker har været til, med jægerstenalderens køkkenmøddinger som et af de tidligste på dansk grund. ${ }^{4}$ Set i det lys går lossepladsens forskningshistorie tilbage til midten af 1800-tallet, men forskningen inden for lossepladser fra nyere tid er dog ganske ung og som oftest begrænset til et meget teknisk og naturvidenskabeligt fokus. Den eksisterende litteratur om lossepladser er i overvejende grad karakteriseret af lossepladsernes forureningsmæssige indvirkning på det nutidige naturmiljø. ${ }^{5}$ Enkelte beskæftiger sig med lossepladserne i et byplanmæssigt perspektiv, men med fokus på de nuværende bebyggelsesmiljøer, som blev etableret oven på affaldet frem for affaldet selv. ${ }^{6}$ I skraldets kulturhistorie er det primært perioden fra 1800-tallet og frem, der har været behandlet. ${ }^{7}$

For emnet affald er disciplinen 'Garbage archaeology' en uundgåelig indfaldsvinkel, men også denne beskæftiger sig primært med nutidens affald. Garbage archaeology, også kaldet Garbology, er det videnskabelige studie af affald og den måde, hvorpå det reflekterer livsstilen hos en affaldsproducerende gruppe af mennesker. Begrebet blev først introduceret i den akademiske verden i 1971 af professor William Rathje fra University of Arizona i en tid, hvor der kom fokus på jordens ressourcer og menneskets affald. ${ }^{8}$ Disciplinen har en både arkæologisk, etnologisk og antropologisk tilgang til affaldet og har vundet popularitet i de seneste årtier med den stadigt øgede opmærksomhed på nutidens forbrug, affaldshåndteringsadfærd og de miljømæssige konsekvenser af måderne at håndtere affaldet på. I Garbology er affald en værdifuld kilde til hverdagen og harmo-

3 Damsholt et al. 2009.

4 Betegnelsen "losseplads" er af forholdsvis nyere dato. Betegnelsen findes tilsyneladende ikke på skrift i dansk sammenhæng før 1718. Nielsen 1872, KD, Bind VIII, nr. 704. Politi- og Kommercekollegiet 20. maj 1718. "...lodsepladserne her i staden, hvor ureenligheden skal aflegges,...". Før dette ord blev gængs, blev fænomenet omtalt som en plads til henlæggelse af urenlighed, møg eller skarn samt plads til opfyldning - og lignende formuleringer. Nielsen 1872 nr. 535 og nr. 1065 som eksempler herpå.

5 Lanzky og Olsen 1999; Pedersen 2004; Pade og Paamand 2008.

6 Seasholes 2003.

7 Hilden 1973; Mikkelsen 1991; Eriksen 1996.

8 Rathje 1981; Schiffer 1981, s. 67; Rathje \& Murphy 1992; Hawkins \& Muecke 2003. 
nerer godt med den historiske arkæologis og den nyere tids arkæologiske tanke om også at være stemme for de dele af samfundet, der ikke kommer tydeligt til udtryk i eksempelvis de skriftlige kilder og i billedkunsten, idet alle efterlader affald. ${ }^{9}$ Forholdet mellem reel og ideel opførsel er også central i garbologien, da studier af affald og interviews med de affaldsproducerende grupper viser, at det vi siger, og det vi gør, ikke altid stemmer overens. Mindre frugtbar er garbologien, når affaldet studeres uden kendt affaldsproducent, hvilket er vilkår, som man ofte må arbejde med inden for arkæologien.

Den kulturhistoriske og affaldsarkæologiske vinkel er ført videre på dansk grund af bl.a. arkæologerne Lene Høst-Madsen og Rikke Kristensen, som i 2005 udgav artikel om lossepladsudgravningen på Esplanaden 50 i tidsskriftet Fabrik $\mathcal{E}$ Bolig på et tidligt stadie i efterbearbejdningen. De kulturhistoriske undersøgelser af lossepladser i Danmark er stadig på et tidligt stadie i udviklingen, og der er behov og grundlag for mange flere bidrag.

Denne artikel er bygget op efter hvilke vinkler, der kan hjælpe til at besvare spørgsmålene, som omhandler affaldskulturen, behovet og tidspunktet for lossepladsens opståen, hvordan den så ud og materialiserede sig lokalt i byrummet. Der indledes med lossepladsen i en lokalhistorisk, topografisk og udviklingsmæssig kontekst. Derefter undersøges dens datering, det fundne affald og lossepladsens udseende. De forskellige typer af kilder inddrages løbende artiklen igennem. Artiklen afsluttes med refleksion over fremtidige muligheder på området. 


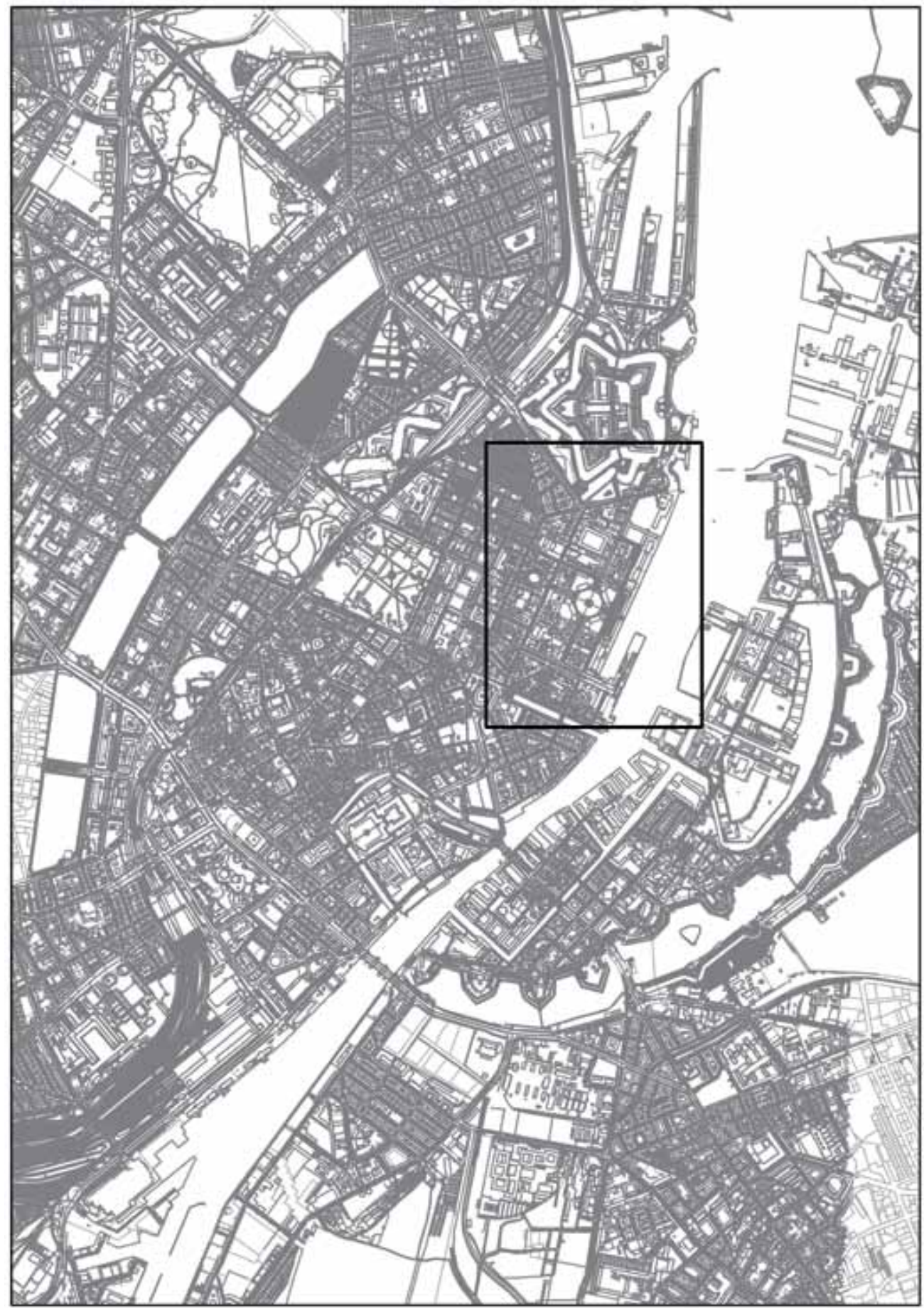

Frederiksstaden i nutidens København. Grafik: Karen Green Therkelsen, Københavns Museum. 


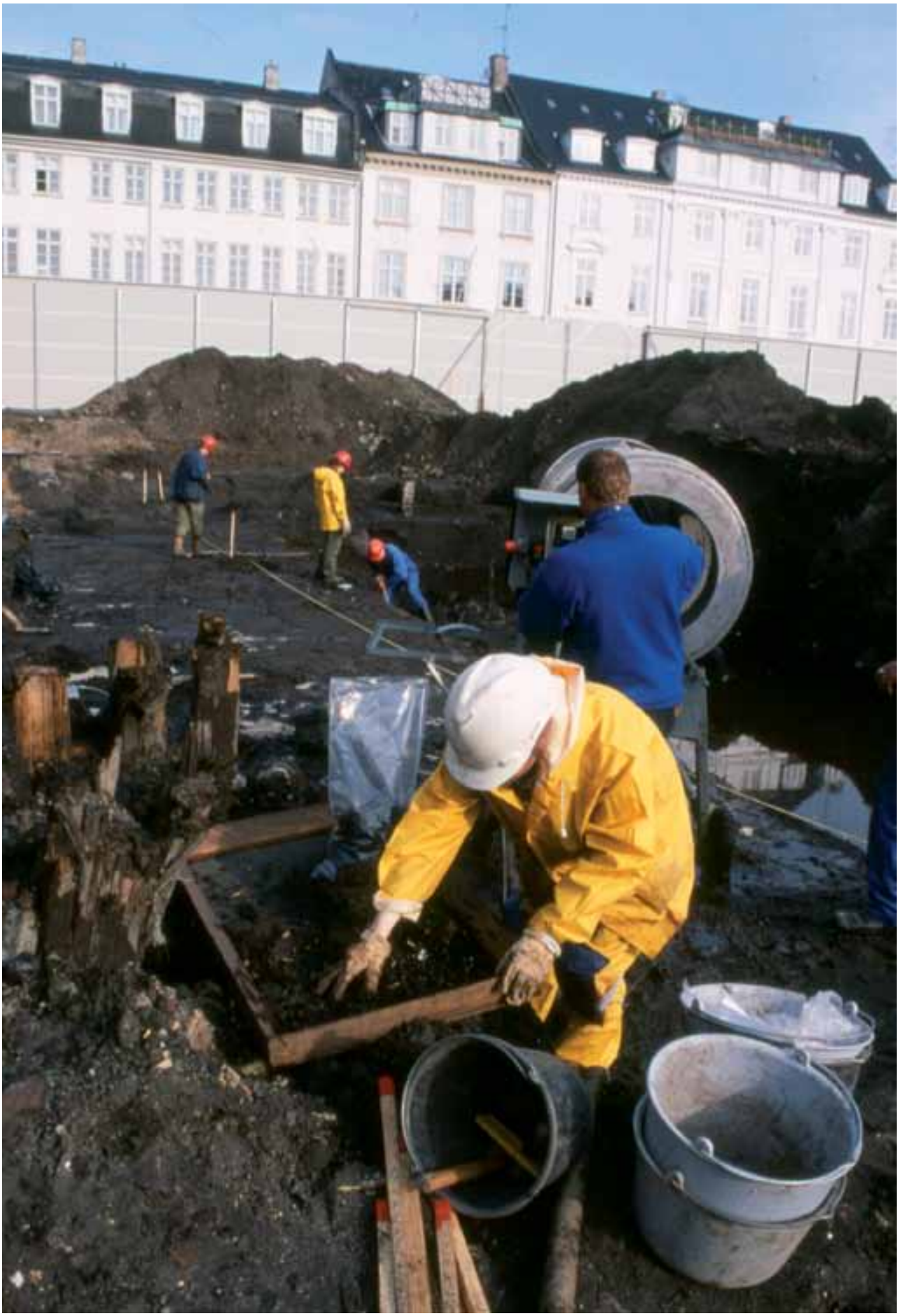

Arkæologisk udgravning på Esplanaden 50, København, 2003. Foto: Vivi Lena Andersen, Københavns Museum. 


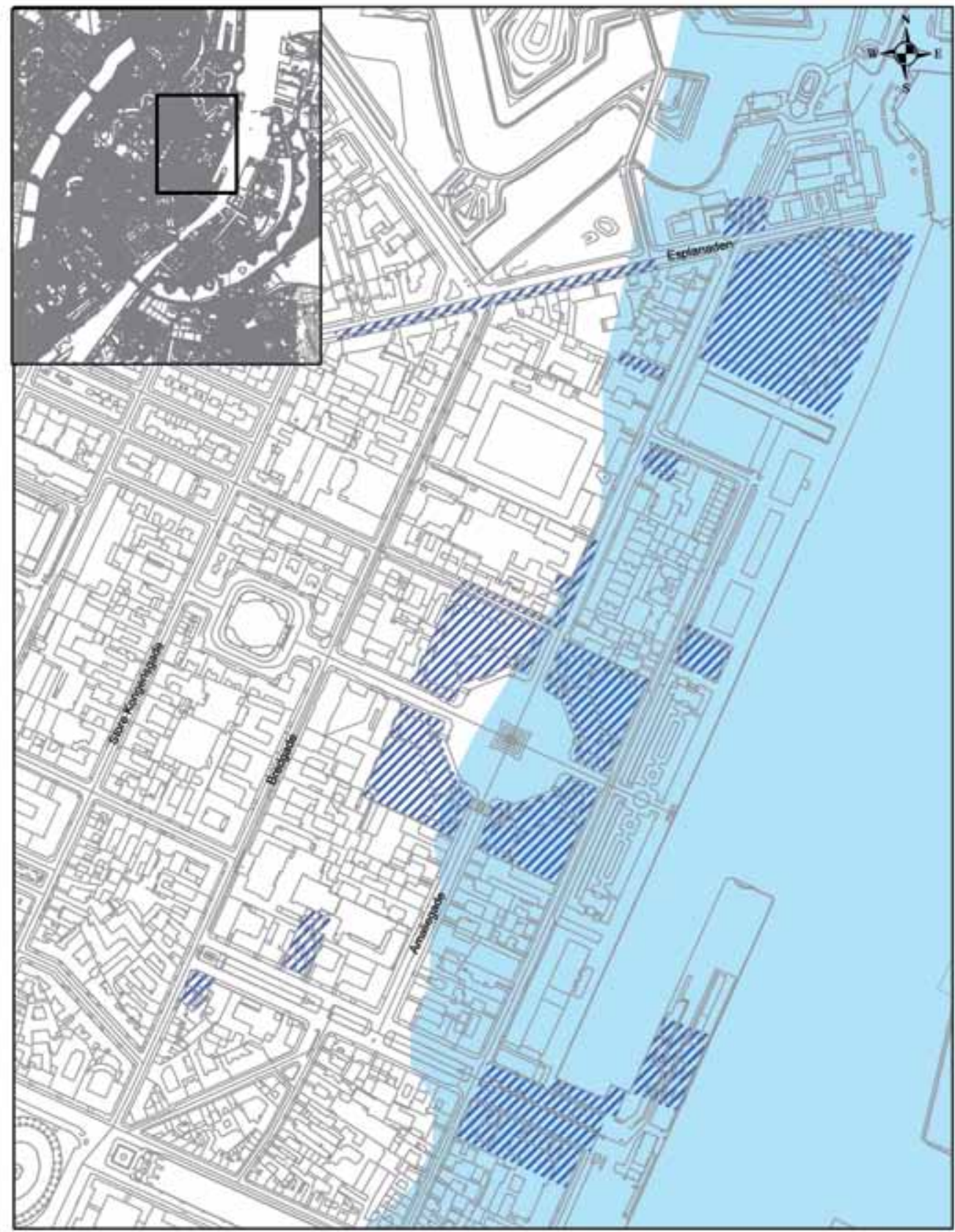

Kort over udbredelse af lossepladsen under Frederiksstaden (skravering) ud fra de arkæologiske udgravninger og iagttagelser, som er foretaget i området. Den oprindelige kystlinje er markeret med lyse blåt i højre side af kortet. Grafik: Karen Green Therkelsen, Københavns Museum. 


\section{København - affald og byudvikling}

København er siden den tidligste bosættelse i jægerstenalderen vokset ved en kontinuerlig opfyldning med forskellige former for affald. I en tid, hvor fænomenet skraldemand endnu ikke eksisterede, var folk selv ansvarlige for håndteringen af deres eget affald. Det betyder, at arkæologer, der graver i København, finder middelalderens affald centreret inden for den datidige befæstning, der hvor folk boede, arbejdede, handlede og levede. I baggården eller haven, på gaden, i voldgraven, ved havnen, langs kysten m.v., hvilket er kendetegnende for middelalderbyer i al almindelighed. ${ }^{10}$ Byen ekspanderede fra middelalderen og frem ud i kystområdet samt i højden ved opfyldning med affald. ${ }^{11}$

Den første officielle, af bystyret bestemte, plads til henlæggelse af affald blev formentlig først etableret i midten af 1500-tallet, da sejlrenden ved Bremerholmen skulle opfyldes og gøre denne holm landfast. ${ }^{12}$ Og senere, i 1617, da anlæggelsen af Christianshavn blev påbegyndt, foregik dette også med bevidste opfyldninger med bl.a. affald.

Som det fremgår af indledningen, er et af de fornemmeste bykvarterer i København bygget oven på en losseplads fra enevældens tid. Fundamentet til Skt. Annæ Kvarter, også kaldet Frederiksstaden, der i dag huser bl.a. Amalienborg og Mærsks hovedsæde, kom til i løbet af 1600- og 1700-tallet i form af affald fra den befolkning, der levede inden for byens befæstning.

Mange matrikler i Frederiksstaden har haft og har stadig arkæologisk interesse grundet tilstedeværelsen af en af enevældens lossepladser på stedet, og det er disse udgravninger, denne undersøgelse tager sit udgangspunkt i. ${ }^{13}$

\section{Frederiksstadens topografi}

Området under Frederiksstaden har oprindeligt været vådområde med strandsand indeholdende muslingeskaller. Derunder ses istidens moræneler. ${ }^{14}$ Der er arkæologisk ikke fundet kulturhistoriske spor i dette område fra tiden før 1600-tallet, så det tyder på, at området indtil da har ligget hen som sump uden egentlig funktion. ${ }^{15}$

I begyndelsen af 1600-tallet påbegyndtes planlægningen og anlæggelsen af Sankt Annæ Skanse mod nord, det senere Kastellet, og denne blev forbundet

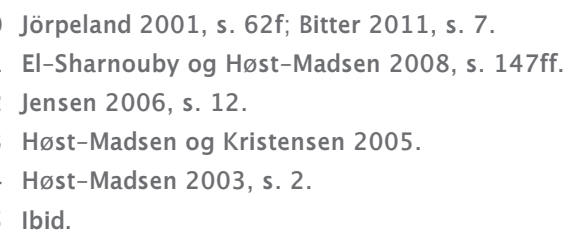


med søerne som et led i udvidelsen af byens fæstningsværker. ${ }^{16}$ Dette medførte, at de våde og sumpede engområder, som lå omtrent, hvor Bredgade ligger i dag, kom til at ligge beskyttet og blev dermed attraktive til bebyggelse. En egentlig byudvikling påbegyndtes dog først med byplanen af 1649, der med havnegader og kunstige øer ville have inddraget området aktivt i det såkaldte Nykøbenhavn, hvis planen var blevet gennemført. Kun få grundarealer blev imidlertid udlagt til bebyggelse i dette område, inden planerne ændredes markant i 1660`erne. ${ }^{17}$

I 1660 opkøbte Dronning Sofie Amalie området mellem det nuværende Bredgade og den daværende kystlinje for at opføre et sommerslot, omtrent hvor Amalienborg ligger i dag. Slottet brændte ned under en teaterforestilling i 1689. ${ }^{18}$ Området ved det nuværende Amalienborg blev herefter brugt som park og til lysthaver, indtil Frederik IV opførte en eksercerplads i 1729.

Arealet nord herfor, tættere Kastellet, henlå helt frem til 1680'ernes slutning som et lavvandet udkantsområde uden egentlig funktion. Først med forlængelsen af Toldbodgade i øst frem til den nordligt liggende Toldbod i årene efter år 1700, blev området endegyldigt afsnøret fra havnens vand, og en egentlig opfyldning af området kunne begynde. ${ }^{19}$

Fra 1749 begyndte byggearbejderne i det nye kvarter mellem Bredgade og havnen med anlæggelsen af en fornem bydel, som var inspireret af italienske byplaner. Bydelen blev navngivet Frederiksstaden efter den regerende konge, Frederik $\mathrm{V}$, og her rejste sig en række adelspalæer; heraf de fire Amalienborgpalæer. Tømmerpladserne, der lå nord for Amalienborg, flyttede fra Toldbodgade i 1755, således at Frederiksstaden kunne rundes af med en passende havnefront. ${ }^{20}$ Man ønskede med andre ord at opgradere området fra søsiden ligeså. Ved Toldboden og den foranliggende Toldbodplads, syd for Kastellet, var der et mangfoldigt leben af ud- og indgående skibe og fartøjer og folk der, især om sommeren, forlystede sig med udsigten til havnen og værtshusene her. ${ }^{21}$ Folk boede, levede og færdedes således tæt på de områder, hvor der samtidig, skiftevist har været transport, aflæsning og deponi af affald.

\section{Lossepladsen under Frederiksstaden - omfang og placering}

De rundt regnet 30 arkæologiske udgravninger og registrerede iagttagelser af lossepladsaffald, der siden 1947 har været i området for Frederiksstaden, viser, at

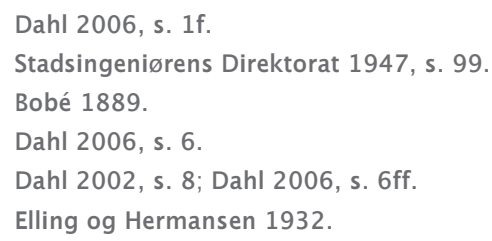


udstrækningen af lossepladsen snor sig fra Churchillparken ved Kastellet i nord til Sankt Annæ Plads i syd og fra havnefronten ved Amaliehaven og Kvæsthusbroen i øst til Bredgade i vest som værende lossepladsens yderpunkter. ${ }^{22}$ Især den vestlige afgrænsning af lossepladsen på det mere faste land er ikke lige i sin afgrænsning. Eksempelvis har man fundet lossepladslag i den sydlige del af Bredgade (Bredgade 20-24 og Sankt Annæ Plads 2) mens afgrænsningen lidt længere nord for går til omtrent den vestlige ende af Esplanaden.

En klarere afgrænsning har der dog været ud mod havet i form af Toldbodgade samt bolværker langs havnen. Ved Sankt Annæ Plads, hvor det nuværende Skuespilhus er placeret, havde man fyldt affald mellem bolværkerne og bygget nye bolværker uden på de gamle, således at hver fase af udbygningen let lader sig datere ud fra det affald, der blev brugt som fyld i mellem de enkelte stolper. Samme princip ses i andre byer. Eksempelvis i Køge, hvor de kontinuerligt udbyggede bolværker langs Køge Å gemmer på genstandsmateriale i form af affald fra omkring 1550 til begyndelsen af 1700-årene. ${ }^{23}$ Det er i området tættest på kysten under Frederiksstaden, at der er fundet mest affald. Vandets dybde er blevet udnyttet til fulde og har skjult en del af affaldet af vejen samt dannet nyt land.

Ved at se på det tilgængelige kortmateriale fra enevælden bliver man ikke klogere på lossepladsens nærmere omfang og opdeling i de forskellige perioder under Frederiksstaden, for det var tilsyneladende ikke almindeligt at afbillede eller markere lossepladser på kort.

I det nordligste område af Frederiksstaden strækker dateringen af de arkæologisk fundne genstande sig helt op til slutningen af 1700-tallet med en udfasning fra 1760'erne. ${ }^{24}$ Med de arkæologiske fund in mente burde vi have mulighed for at se en del af lossepladsen aftegnet på ingeniørofficer Christian Geddes perspektivkort over København, som blev færdigt i 1761. Kortet var bestilt af kongemagten, og den kongelige ingeniør udarbejdede det kartografiske grundlag. ${ }^{25}$ Geddes arbejde indeholder righoldige detaljer, bygningsrids, haveplaner og udførlige opmålinger, alt sammen udført med stor omhu. På Geddes kort er der skrevet "Friederichsstad” på pladsen mellem Amalienborgpalæerne (den nuværende Amalienborg Slotsplads). Andre palæer med gårdhaver er skudt op i området mellem Norges Gade (nuværende Bredgade), Amalie Gade og Nye Told-

22 Arkæologiske undersøgelser foretaget i Frederiksstaden, hvor der er fundet lossepladslag findes i beretninger på Københavns Museum med følgende id-numre: KBM 409, 498, 1655, 2307, 2831, 2909, 2973 , 3043, 3099, 3100, 3298, 3330, 3433, 3458, 3488, 3492, 3500, 3543, 3608, 3648, 3667, 3672, 3673, 3749, 3825, 3826, 3861, 3904 og 3955. Derudover er der foretaget undersøgelser i Amaliegade 39 (Reg. 1947:142-171c) og Amaliegade 37(1970). Se topografisk arkiv på Københavns Museums antikvariske enhed og sagsdatabasen. Nogle ældre iagttagelser er ikke blevet registreret og forefindes kun som avisartikler og noter uden sagsnummer.

23 Rasmussen 2005, s.106ff.

24 Andersen 2007, s. $90 \mathrm{ff}$. 
bode Gade ved havnen. Nord for Amalienborg ses Frederiks Hospital (nuværende Designmuseum Danmark), som blev oprettet af Frederik V og opført i 1752-1757. På nogle matrikler på kortet ses kun træer eller beplantning, mens der på andre matrikler, især ved Nye Toldbode Gade, intet er på matriklen, hvilket kan betyde, at området var udstykket, men på dette tidspunkt endnu ikke købt eller bebygget. Nordøstligst ses Kastellet, men lige under det ses et område ned mod Toldboden ved havnen, som er opdelt af Amalie Gade. Området udgøres af to store matrikler, der begge er omkranset af en mur med seks porte i. Der er tale om Københavns anden Botaniske Have, som kun lå der i få år, men der er ingen signaturer på den botaniske grund. Der illustreres blot et tomt indhegnet område. Kortet må vise et forslag til en udstrækning af Botanisk Have, da denne plan angiveligt ikke blev fuldstændig effektueret. Den østlige del blev aldrig brugt som Botanisk Have. ${ }^{26}$ Det ser derfor ud fra kortet ud til, at arealet var udstykket til botanisk formål, men realiteten har været en anden. Lossepladsen var, ifølge de arkæologiske fund fra området, i funktion i netop det område, mens kortet blev tegnet, men lokaliteten blev ikke vist.

Selvom det ikke var normen at markere lossepladser på kort, så er der muligvis et enkelt eksempel på det for Frederiksstadens vedkommende. På et kort over Frederiksstaden af Sibrandt, udgivet af Christian Gedde og dateret til begyndelsen af 1730'erne, er aftegnet et cirkulært morads i området mellem Toldboden, Esplanaden og nuværende Amaliegade, som står i klar kontrast til kortets øvrige meget ordnede og lineære afbildning. Det tolkes almindeligvis som et vådområde, men ifølge dateringen af de arkæologiske fund, som næste afsnit omhandler, har der været losseplads i det område på denne tid. Så måske er det sumpede morads, som er aftegnet på kortet, samtidig også indikator for losseplads, idet opfyldningen af dette område har været i gang.

I en senere henvisning, Generalstabens "Ledetraad i Detailmaalingen" fra 1877, angives en lang liste over terrænelementer, som bør fremgå på en kartografs kort. Den lange liste indeholder intet mindre end 85 elementer - eksempelvis enge, bakker, skove, huse, holdepladser, brønde, smedjer, teglovne og toldsteder - men ingen signatur for lossepladser er at finde på listen. ${ }^{27}$ Fraværet kan muligvis skyldes, at disse pladser til affald i samtiden blev opfattet som et midlertidigt forhold. ${ }^{28}$ Derudover var den primære hensigt med udarbejdelsen af datidens kort ikke at afbillede en overfladebeskrivelse med samtlige topografiske elementer, men derimod at fremhæve fysiske træk ved byen, som havde relevans for udlodning af grunde og afklaring af skelgrænser. ${ }^{29}$

26 Botanisk Haves hjemmeside: http://botanik.snm.ku.dk/Ombhm/Havens_historie/have2/ (23.11.11).

27 Generalstabens topografiske afdeling 1877.

28 Ifølge korrespondance med Bjørn Westerbeek-Dahl.

29 Dahl 1991, s. 7; Korsgaard 2006, s. 25 og s. 30ff; Skriver 2008, s. 13. 


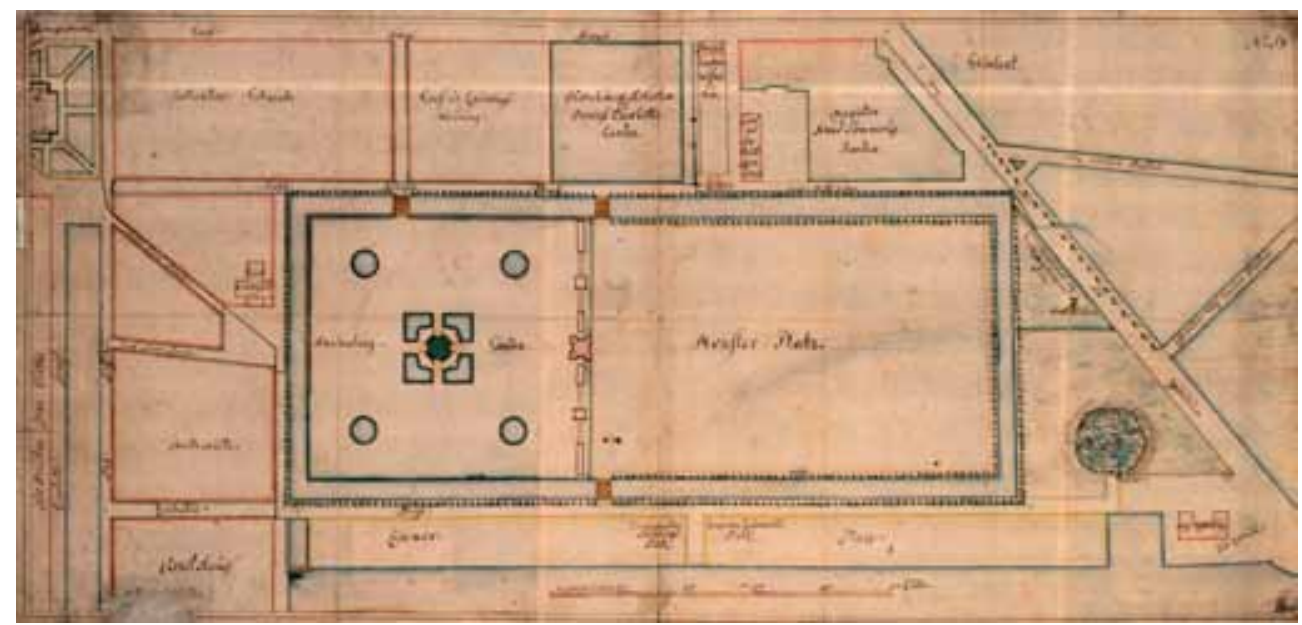

Kort fra ca. 1730 udført af Sibrandt og udgivet af Gedde i 1744. Yderst til venstre ses Nyhavn og i midten det senere Amalienborg. Det cirkulære område, nederst i højre hjørne, er enten gengivelse af område med affald eller et vådområde, som er rede til at blive fyldt op. Rigsarkivet.

Ligesom man ikke fandt det relevant at afbilde lossepladsen, fandt man det heller ikke relevant at anbringe affaldet uden for byen, hvilket umiddelbart kunne virke som det mest rationelle. Hvorfor blev denne losseplads anlagt inde i byen? Hvis målet var at få affaldet væk fra byens gader, torve, voldgrav og beboelse, kan det undre, hvorfor affaldet ikke blev kørt helt ud af byen, ud gennem portene og ud til oplandet. I stedet valgte man at beholde affaldet inden for byens mure.

Ser vi på andre byers grundplaner og placering af affaldspladser, så er København ikke et enkeltstående tilfælde. De gamle byers lossepladser var oftest kystnære med opfyldning ud i selve vandet eller på de lavtliggende kystområder inden for byens rammer, med bl.a. Stockholm, Boston og London som eksempler herpå. ${ }^{30}$ Dette mønster var gældende lokalt helt op til vore dage ved opfyldning af vådområder via anlæggelse af lossepladser i Frihavnen i nord og hele godsbaneområdet i syd samt Kongens Enghave og Valby, der senere blev udlagt til parker og kolonihaver. ${ }^{31}$ Et af de nyeste eksempler er lossepladsen under Amager Strandpark, hvis kystnære placering nu bruges som rekreativt område i form af strand. Ved at deponere affald på de lavtliggende områder i byens periferi, blev der skabt landindvinding, og de nydannede områder langs kysten blev sidenhen brugbare til andre formål. ${ }^{32}$ Dette fremgår også af politimester Johan Bertram Ernst, som i år 1714 skrev: ”..., tilholdes at udføre deris møg eller andet, som kand tiene til opfyldning, til forskrevne elleve pladtzer ... ". ${ }^{33}$ Geotekniske undersøgelser viser, at en tredjedel af Indre København er beliggende uden for den naturlige kystlinje,

30 Jörpeland 2001, s. 62f; Seasholes 2003; Egan 2005.

31 Eriksen 1996, s. 14.

32 Eriksen 1996, s. 16.

33 Nielsen 1872, nr. 535. 
hvoraf dele af det er skabt gennem systematisk opfyldning, blandt andet af byens affald, som tilfældet er under Frederiksstaden. ${ }^{34}$ Affaldskulturen har således indgået aktivt som et led i byudviklingen.

\section{Datering af en losseplads}

Ved arkæologiske udgravninger kan de ellers gængse naturvidenskabelige dateringsmetoder C14 og AMS $^{35}$ være altafgørende for dateringen af et kompleks anlæg eller en genstand, men disse metoder er ikke tilregnelige i den nærværende kontekst, da indholdet af kulstof i atmosfæren fra 1650'erne og frem er for højt til at kunne give præcise målinger. ${ }^{36}$ Dette skyldes den industrielle udvikling i den vestlige verden, da fossilt brændsel i form af kul blev brændt af i store mængder. Kulstoffet i atmosfæren påvirker samtidens levende organismer (træ, planter, mennesker, dyr), således at det naturlige indhold af kulstof forøges, og derved giver et forvansket resultat i forhold til det naturlige indhold af kulstof.

Den traditionelle, arkæologiske, stratigrafiske metode, hvor de fund, der ligger nederst er ældre end de fund, der ligger oven over disse, kan heller ikke bruges i denne lossepladskontekst, idet opfyldningen af lossepladsen skete både vertikalt og horisontalt. Lossepladsen ved Esplanaden blev sandsynligvis fyldt op startende fra det trods alt mere faste land (eksempelvis ved Toldbodvejen) og ud i vandet og i de mere fugtige områder således, at man har kørt hestevognen ud på det i forvejen liggende affald og læsset nyt affald af eller oven på det affald, der allerede lå der (horisontal aflejring) og trillende ud over siden på bunken ud mod kysten (tilnærmelsesvis vertikal aflejring). Dette opfyldningsmønster tyder de arkæologiske udgravninger i al fald på, hvor affaldslagene kan aftegnes som i følgende figur.

Som figuren viser, kunne det under udgravningerne konstateres, at der var forskellige områder og lag med lidt forskellig substans, struktur og farve og med koncentrationer af forskellige genstande såsom kvægstejler og -kranier, glasflasker, sivmåtter, læder og sko, grene etc., sandsynligvis fordi et læs affald bestående af én bestemt type er blevet smidt ud på samme tid - eksempelvis affaldet fra en skomagers værksted. Men generelt er det vanskeligt at iagttage forskel i jordlagene fra område til område på lossepladsen. Det kan formodentlig skyldes nedbrydning, ensartede læs af affald og sekundær omrokering af affaldet. Eksempelvis fortæller en befaling fra Politi- og Kommercekollegiet dateret 6. maj 1710: ”De kontraherende Vognmænd skal strax efter Oldermandens løfte jævne

\footnotetext{
34 Eriksen \& Eriksen 2002, s. 229.

35 AMS er forkortelse for Accelerator Mass Spectrometry, som er en dateringsmetode på blot få milligram kulstof.

36 Deetz 1996 (1977), s. 24.
} 


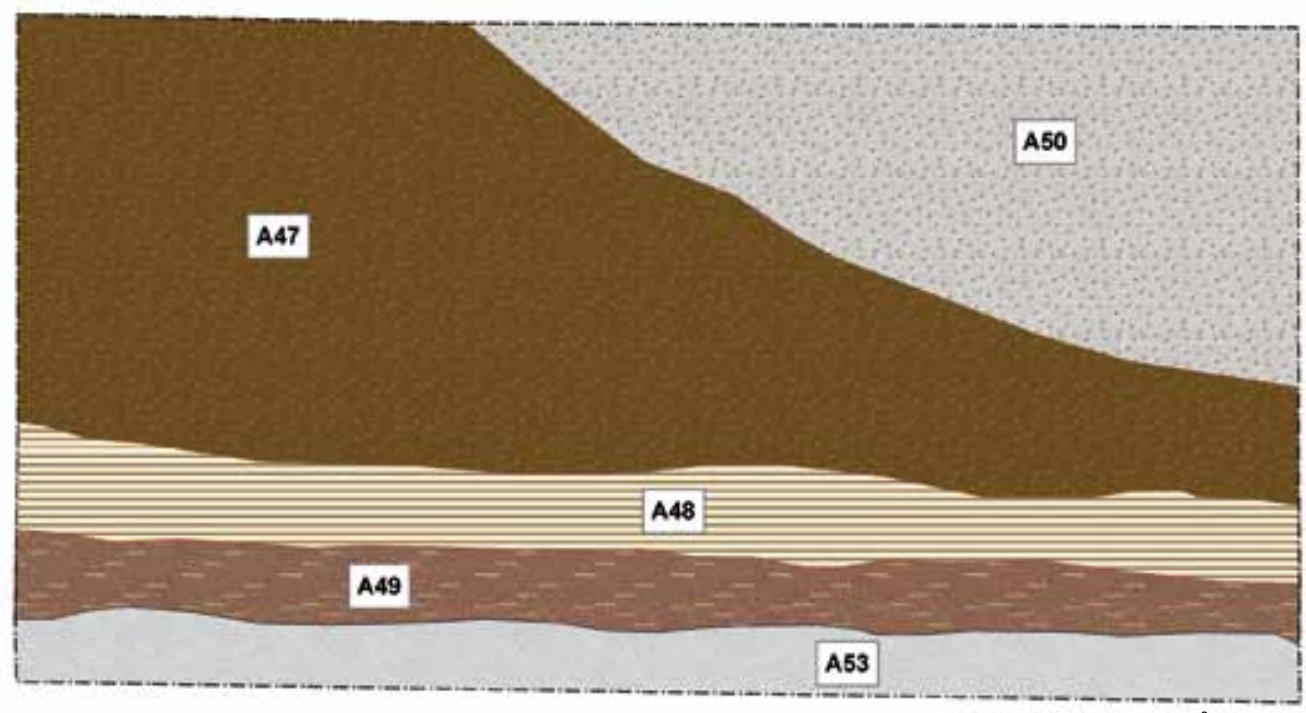

Illustration af hvordan affaldet har dannet forskellige lag. Profiltegning fra udgravning på Esplanaden 50. Selvom alle lagene er affald, så adskiller de forskellige lag sig her en anelse ud fra deres indhold (eksempelvis ved koncentration af en genstandstype), struktur og farve. Grafik: Karen Green Therkelsen, Københavns Museum.

den Urenlighed, som er kastet ved Luses Hul og Tolbodvejen, hvor Træerne staar, saa at Vejen er skikkelig, og holde stedse uden Klagemaal ved lige...”. Det blev således befalet at jævne affaldsdyngerne ved Toldbodvejen, da området allerede var godt fyldt. ${ }^{37}$ Senere, i 1726, skriver kongen til Politi- og Kommercekollegiet om udvisning af pladser til renovation ved Vesterport, Nørreport, Christianshavn og ved Toldboden: "Naar nu Afladningen og Opfyldningen paa alle oven specificerede Stæder skeer, saa skal alle og enhver saavel Indbyggerne og renovations Contrahenterne som Natmanden være pligtige strax at lade planere det, som Enhver haver henført...".38

Det må antages, at planering af affaldet jævnligt har fundet sted. Derudover kan der være sket mindre omrokeringer af affaldet, når klunsere eller tilsynsmænd har rodet i det. Fundsammensætningen i de enkelte områder viser også, at yngre og ældre fund optræder i samme kontekst, hvilket kan være udtryk for de forskelligartede genstandes asynkrone omløbstid, men også at affaldet er blevet omfordelt via senere udjævninger.

For at datere lossepladsen arkæologisk er man nødt til at se på den typologiske datering af de genstande, der udgraves. Af de rundt regnet 100.000 genstande, som kom frem under udgravningerne, er majoriteten forsøgt dateret ud fra en kombination af materiale, form og dekoration. De ældste fund stammer fra 1600-tallet og de yngste fra 1700-tallets slutning. I dette regnestykke skal til- 
lægges betragtninger om en genstands omløbstid - dvs. en genstands livscyklus. Finder man eksempelvis bundskåret fra en fornem vase, der er produceret i slutningen af 1600-tallet, så kan denne være smidt ud 100 år senere som antikviteten, der faldt ned fra bordet. Det er derfor vigtigt at se de store sammenhænge i det omfattende fundmateriale, samt fokusere på de genstandstyper, som har en hurtig omløbstid såsom kridtpiber og sko. Ud fra dateringen af servicet og køkkentøjet fra lossepladsen under Esplanaden 50, dækker lossepladsens fund hele 1700-tallet med en overvægt på første halvdel af århundredet og særligt midten af 1700-tallet. ${ }^{39}$ Enkelte fund stammer fra hhv. slutningen af 1600-tallet og slutningen af 1700-tallet. Kridtpiber, der er talrigt repræsenteret, er forholdsvis lette at datere inden for en kortere periode på ca. 40 år, og nogle kan endda dateres meget eksakt, i fald kridtpiben har årstal eller værkstedsstempel på sig. ${ }^{40}$ Derudover havde kridtpiber en ganske kort levetid på angiveligt kun 14 dage. ${ }^{41}$ Det skyldes, at de blev brugt ofte, var skrøbelige i deres lange, tynde form og af tyndt, keramisk materiale og derfor nemt gik i stykker, når de blev tabt. Endvidere fandtes også offentlige, fælles kridtpiber, som herrerne kunne låne, mens de befandt sig på datidens værtshuse. Når man lånte en kridtpibe, knækkede man den øverste del af stilken af, så man fik et rent mundstykke at ryge på. Disse små, afbrækkede stykker af stilken findes i store mængder arkæologisk, og de viser den korte omløbstid for sådanne piber.

Skoene er ligeledes gode i dateringsmæssigt øjemed, idet de bruges ofte, hurtigt bliver slidt og efterfølgende kasseres. Man mener, at en sko fra perioden har haft en omløbstid på mellem to og fire år. ${ }^{42} \mathrm{Ud}$ fra skomoden i denne periode er det muligt at datere sko inden for et tidsafsnit på 20 år. Dateringen af alle de daterbare sko og skodele fra lossepladsen under Esplanaden 50 stemmer fint overens med dateringen af servicet og køkkentøjet, da det primært er sko fra midten af 1700-tallet, der er blevet læsset af her, og der er fundet sko fra såvel 1680'erne som 1780'erne. En mønt fra 1762 samt enkelte stykker engelsk industriporcelæn sætter som nogle af de yngste fund det tidsmæssige punktum for deres produktionstidspunkt til 1760'erne, men tidspunktet for hvornår, de er deponeret på lossepladsen, kan være senere end det.

En samlet datering af alle genstandstyperne fra lokaliteten på Esplanaden 50 strækker sig over knap 100 år. Hvordan harmonerer dette med oplysningerne fra de skriftlige og kartografiske kilder? Påbegyndelsen af opfyldningen i området passer fint med årene omkring år 1700, mens afslutningen på opfyldningen har sine uoverensstemmelser. Det er det generelle indtryk ud fra både de skriftlige og de kartografiske kilder, at opfyldningen slutter omkring 1750, da anlæggelsen af

39 Kristensen 2004.

40 Oswald 1975.

41 Rahbek og Pram 1794, s. 181.

42 Andersen 2007, s. 85ff; Gräslund 1996. 
kvarteret og byggerierne påbegyndes på dette tidspunkt, men affaldslagene fortæller en anden historie. Affaldet viser, at der fortsat blev læsset affald af i det pågældende område indtil slutningen af 1700-tallet, og det må være det sidste område til officielt at blive inddraget i Frederiksstaden som led i prestigebyggeriet. Planerne har muligvis været nogle andre, men med periodevis anden benyttelse må enten skraldemændene eller Københavns indbyggere fortsat have benyttet området til bortskaffelse af noget af deres affald.

Sammenlignes dateringerne af fundene fra Esplanaden 50 med de øvrige arkæologiske udgravninger i Frederiksstaden, ses levn fra en lang periode, men det er samtidig også tydeligt, at den tidligste opfyldning primært skete nord for Nyhavn (ved Sankt Annæ Plads), nemlig i midten af 1600-tallet, og bevægede sig længere nordpå op langs kysten først i 1700-tallet for til sidst at indfinde sig massivt ved Esplanaden i midten af århundredet og derefter tynde ud mod 1700-tallets slutning.

\section{Behovet for en losseplads}

Med affaldspladsen fremkom et nyt rum i det urbane landskab, men hvorfor opstod behovet for lossepladsfunktionen på netop det tidspunkt? Én af de mest iøjnefaldende faktorer er den høje befolkningstæthed inden for byens rammer, som har gjort det gradvis vanskeligere for den enkelte uforstyrret at henkaste sit affald.

København var i 1700-tallet Danmarks hovedstad med både adelige, politiske, militære, kommercielle og kulturelle aktiviteter. Indbyggerantallet var højt med ca. 90.000 indbyggere i slutningen af århundredet. Til sammenligning var der i Danmarks næststørste by Odense kun noget over 5.000 indbyggere i samme periode. ${ }^{43}$ I løbet af 1700-tallet steg befolkningstallet primært som følge af stigende levealder, fald i fødselsdødeligheden samt en lang periode uden Danmarks deltagelse i krig. ${ }^{44}$ Befolkningstallet i København voksede med 40 pct. i slutningen af 1700-tallet. Den voldsomme stigning i befolkningen i København betød, at affaldsmængden voksede og blev et større og mere påtrængende problem, som krævede forordninger og handling. Desuden var århundredet begyndt med en voldsom pestepidemi i 1711, som også kan have forstærket nødvendigheden af, at affaldet blev fjernet til afsides liggende pladser. Frederik IV skrev til politimester Johan Bertram Ernst d. 6. maj 1712,

"Vor Bevaagenhed tilforn. Saasom vi ugierne have maat fornemme, at Skarnet og Ureenligheden ligger i Mængde paa Gaderne i vores etc. Kiøbenhafn ubortført,

43 Bregnsbo 2009, s. 133; Henningsen 2009, s. 326.

44 Eriksen 1996, s. 16. 
endskiønt der saa meget contribueres af Huszene til deris reenholdelse, som da der af endnu kunde foraarsages smitsom Sygdom, i det Børn og gemeene Folk derudi kunde søge efter Lumper og andet Tøy, som af de Huse, hvorudi Contagion haver været, kunde vere bleven udkast, og saaledes dermed ny Ulykke antændes, saa er vores etc., at du aldeelis lader dig vere angelegen, at ald saadan Ureenlighed uden ringeste ophold og forsømmelse bliver ført ud af Byen og henlagt saaledes, at der af ingen Fare kunde vere at befrygte og Gaderne altid holden reene. ${ }^{45}$

Kongen frygtede med andre ord, at kasserede ejendele fra pestsyge kunne smitte, hvis det lå i gaderne, og ønskede dette fragtet bort.

Den af bystyret bestemte losseplads opstod dog før pestepidemien og faldt snarere sammen med indførelsen af de første matrikler i byen i $1689 .{ }^{46}$ Enevælden, der indføres i 1660 af Frederik III, var en centralisering af magten og statsadministrationen, således at kongen havde det fuldstændige herredømme over København. Enevældens idé gik ud fra, at uden fælles styring lever folk i alles krig mod alle. En centralmagt skulle indføres for at beskytte mennesker mod hinandens overgreb. Et af de vigtigste mål var at bringe orden og ensretning i landet og i hovedstaden, hvilket blev forsøgt gennem adskillige love og forordninger om alt lige fra gaderenholdelse til skatteopkrævninger. Ved at opmåle grunde og registrere deres ejerforhold blev det lettere at indkræve skatter. Dette nye system af ejerforhold og indførelsen af skarp skelgørelse kan have været medvirkende årsag til, at affaldet skulle bortskaffes til et neutralt sted, hvortil ingen indbyggere havde ejerforhold.

Matrikuleringen kan have udviklet denne øgede ejerfornemmelse af grund og skel og gjort affaldet til "matter out of place”, som antropolog Mary Douglas beskriver det. ${ }^{47}$ Ifølge Douglas findes snavs ("dirt") ikke. Snavs, eller her affald, bliver først et problem, når et samfund klassificerer det som værende uorden, hvilket defineres af dets kontekst. ${ }^{48}$ Under enevældens organisering af samfundet er det tydeligt, at affald gennemgik en klassificering, hvor dets tilstedeværelse i bybilledet ikke længere var acceptabelt ifølge statsadministrationen. Ting skulle nu have deres rette plads. Affald skulle deponeres på de udpegede, neutrale, marginale områder for at opnå den ønskede orden, og derudover kunne affaldet danne basis for udvidelse af byen.

Ejerfornemmelsen for ens grund har utvivlsomt altid været til stede, men da det blev gjort officielt i form af matrikuleringerne, fremmede det bevidstgørelsen

\footnotetext{
45 Nielsen 1872, nr. 366.

46 Kjøbenhavns Huse og Indvaanere efter Branden 1728 1906, s. VI.

47 Douglas 2006 (1966).

48 Douglas 2006 (1966), s. 197; Thompson 1979, s. 91f; Mikkelsen 1991, s. 5.
} 
af fænomenet. ${ }^{49}$ Dette set sammen med de øgede gener fra de mange indbyggeres affald i byen, som kommer til skriftligt udtryk i klager og de mange renholdelsesforordninger, har gjort affaldet på gaderne og på matriklerne "out of place".50

Ved arkæologiske udgravninger i indre København, er det reglen, og ikke undtagelsen, også at finde affald fra 1700-tallet på de daværende gader, selvom mængden givetvis er væsentlig mindre end for middelalderens vedkommende. Men også baggården blev under enevælden stadig brugt som privat losseplads, selvom et nyt affaldshåndteringssystem dikterede noget andet. Indholdet af en latrinkasse fra starten af 1700-tallet, som blev udgravet i baggården til Pilestræde nr. 8, fortæller os, at husholdningsaffald samt fejeskarn blev kastet i latrinkassen. ${ }^{51}$ Enevældens system med afhentning af affaldet, så det ikke blev deponeret rundt omkring i byen eller på folks egne matrikler, var en udfordrende og langvarig proces at forankre. Folk ændrede ikke adfærd fra den ene dag til den anden.

\section{Affaldet under Frederiksstaden}

De omkring 100.000 genstande, som er fundet under de arkæologiske udgravninger i Frederiksstaden, afspejler, hvad befolkningen i enevældens København valgte at skille sig af med. De afklippede parykker, det skårede porcelæn, de knuste fajancetallerkner, de udtrådte sko, de genbrugte klude, de lappede strømper, de knækkede kridtpiber, de stablede æggeskaller etc. er alle genstande, som endte på enevældens losseplads. Sammen afspejler de hverdagskulturen fra høj og lav i samfundet, og deres tilstand og livscyklus kan fortælle om affaldskultur ud fra genstandenes spor af brug, forbrug og genbrug.

Fund fra en losseplads hører til den kategori af affald, der af arkæologer betragtes som sekundært affald, ${ }^{52}$ det vil sige affald, der er transporteret bort fra det sted, hvor det blev brugt oprindeligt. Det er langtfra alt, som umiddelbart kan relateres til de enkelte husholdninger i byen. Materialet taber noget af sin kildeværdi, når proveniensen er usikker, men det besidder stadig et potentiale, når man tager udgangspunkt i genstanden selv, og fortolker den på dens egne præmisser som et emne med egen livscyklus og formationsproces. ${ }^{53}$ Den enkelte genstand kan eksempelvis give os indsigt i handel, produktion, brug, forbrug, genbrug og kredsløb af genstande i det pågældende samfund ud fra håndværkerens arbejdsmetoder og teknik, reparationer, modificeringer samt slitage fra én

9 Branton 2009, s. 56.

50 Wiene 2013 in prep.

51 Andersen 2004, s. 8ff; Andersen og Moltsen 2008.

52 Schiffer 1972.

53 Damsholt \& Simonsen 2009, s. $17 f$. 


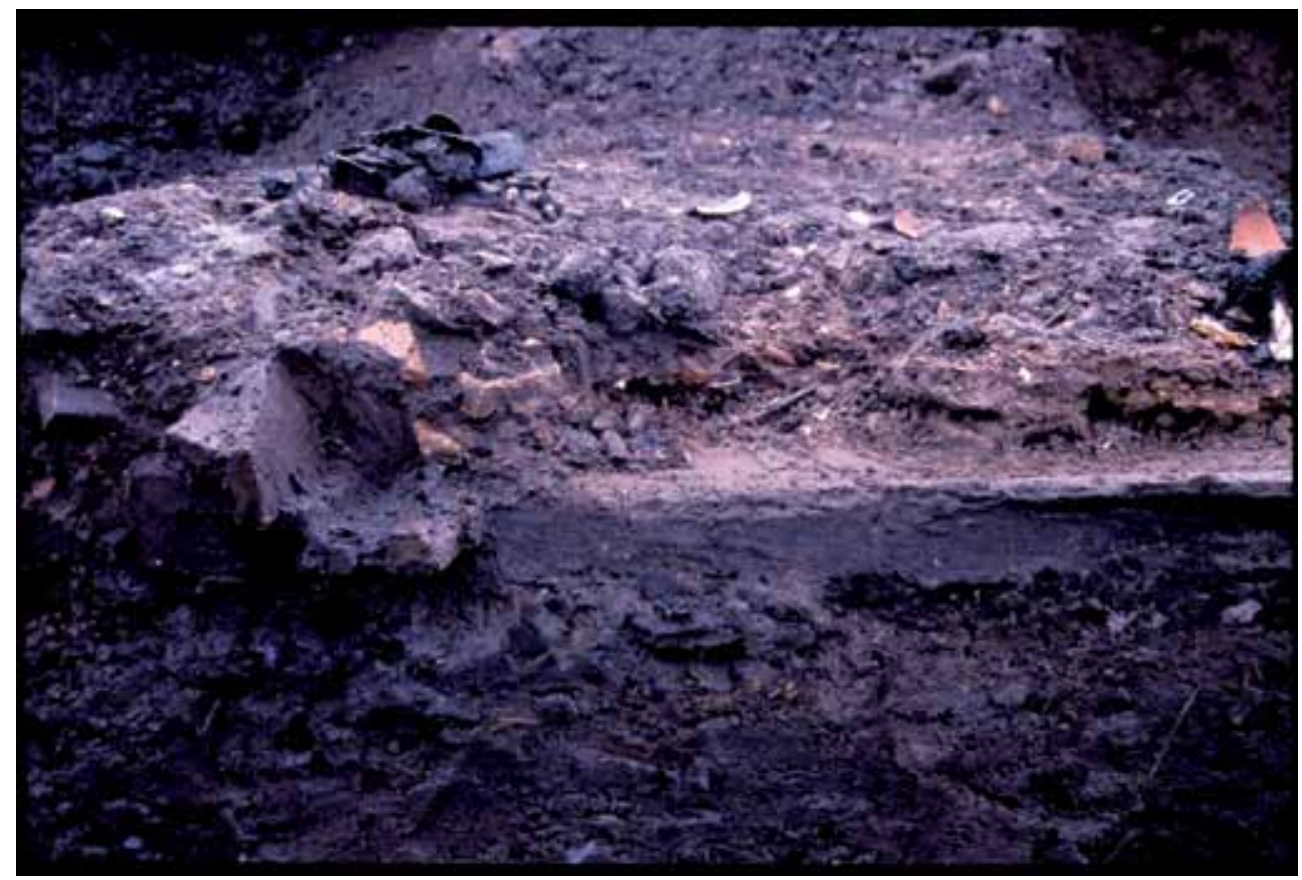

Foto fra udgravning af losseplads, hvor man ved nærmere eftersyn kan se lædersko, tekstil, kridtpiber, keramikskår, knogler og meget andet. Foto: Vivi Lena Andersen, Københavns Museum.

eller flere ejere. ${ }^{54}$ Indgangsvinklerne og analyserne af de arkæologiske genstande fra en losseplads er mange, men i nedenstående afsnit fokuseres på elementer, der bidrager til nærværende problemstilling.

\section{Affaldet under Esplanaden 50 - brug, forbrug, genbrug og affaldskultur}

Herunder præsenteres det fundne affald for udgravningen på Esplanaden 50. Fund fra netop denne udgravning er valgt, fordi de udgør det største, mest systematisk udgravede og bedst registrerede fundmateriale, som tilmed havde optimale, iltfattige bevaringsforhold. Typerne af fundene er lig de mindre udgravningers fund, så overordnet set er udgravningen repræsentativ for de øvrige udgravninger.

Selvom husholdningsaffald dominerer fundet, så er en temmelig stor andel af lossepladsens affald fra Esplanaden 50 fra industri, håndværk og handel. Her kan nævnes læderfraskær fra skoproduktion og skoreparation, hornstejler ${ }^{55}$ fra garveri, slagteri og/eller hornmager, slagge fra metalhåndværk, fejlbrændt fajance

54 Rathje \& Murphy 1992.

55 En hornstejle er et horns indre og er sammenvokset med dyrets pandeben. 
og plader fra fajanceproduktionen fra den nærved liggende Store Kongensgadefabrik, affald fra knappemageri, klædeplomber, ${ }^{56}$ reb, snore, seletøj, trætønder, træskafter fra værktøj, apotekskrukker og mønter, men også affald fra byggeri eller nedrivning af huse/dele af huse/lejligheder såsom gulvfliser, vinduesglas (som var lysegrønne), søm, teglsten og nøglehulsbeslag.

Fra husholdningen er der kasserede ødelagte gryder, pander (af lertøj), stegefade, sifade, serveringsfade, skåle, potter, kar, dunke, krukker, knive, rivejern af metal, kost, børster, dyreknogler, ${ }^{57}$ æggeskaller, som er affald fra madlavningen, samt selve maden (løg, blomme, æble, krydderier). Affald fra måltiderne ses i form af ødelagte tallerkner, drikkeglas, terriner, kander, krus, kopper, underkopper, skeer, flasker, korkpropper og duge. Stuerne er repræsenteret ved porcelænsfigurer, vaser, kakler fra en brændeovn, tranlamper og dele af gardiner. Fra soveværelserne er der natpotter, dele der engang udgjorde tæpper og sengelinned samt bastmåtter. Også haveaffald findes i lossepladsen som dele af havevaser og urtepotter.

Det mere personlige affald er repræsenteret i affaldet i form af dele af tøj (hatte, handsker, strømpebånd, bukser, veste, jakker, kjoler, korsetter (i form af hvalbarde anvendt som stiver) etc.), knapper, sko, metalspænder parykker, kamme, vifte, knappenåle, fingerbøl, salvekrukker, kridtpiber, spillekugler, snurretop, trædukke, bogbind, sparebøsse, seglstampe og en nøgle.

Affald med militært islæt ses i form af en grenarderplade, som har siddet på huen af den soldat, der var grenarder (dvs. den "granatansvarlige") samt uniformsknapper med anker på.

De ovennævnte objekter er enten lokalt produceret eller importeret fra Bornholm, Jylland, Tyskland, Holland, England eller Kina som de primære eksempler på oprindelsessteder.

Det kan være vanskeligt at spore genbrug ud fra genstande fundet på en losseplads, idet genstanden er fjernet fra dens oprindelige kontekst. Mange af genstandene kan være genbrugte på forskellig vis og kan have skiftet ejer, men det kan ikke altid ses ud fra genstanden alene, når den findes på en losseplads. Eksempelvis fremkom en køkkenpotte i en latrinkasse i gården til Pilestræde nr. 8, hvor den tydeligvis var blevet genanvendt som natpotte. ${ }^{58}$ Mange af lossepladsens fund kan have haft lignende skjulte genbrugsskæbner, inden de ankom til lossepladsens sammensurium. Men der er fund fra lossepladsen, som i sig selv vidner om genbrug. Kun enkelte stykker af det dyre, importerede kinesiske porcelæn har spor efter klinkning, hvorimod det var ganske almindeligt at klinke det billigere fajance og lertøj. Der ses også et eksempel på en fajancepotte, hvori der er lavet hul i bunden, så denne kunne genbruges som urtepotte. De mange afbrækkede

56 Klædeplombe er et segl af bly, som blev stemplet fast til tekstil, som bevis for ægthed og oprindelse.

57 Enghoff 2004.

58 Andersen 2004, s. 9. 
kridtpibestilke kan vidne om den tidligere nævnte praksis på traktørsteder, hvor man genbrugte en fælles kridtpibe og knækkede den yderste del af stilken, så den var klar til næste rygende gæst.

Også i de mange fundne lædersko, kan der spores en frekvent genbrugspraksis. Størstedelen af de fundne sko og skodele har spor efter reparationer, der har forlænget levetiden. Der ses også mange eksempler på sko, som er blevet modificerede, så de kunne passe en ny ejers fod, eksempelvis ved at bagkappen er blevet skåret af skoen, så den blev omdannet til en tøffel og kunne passe til en større fod. Der er noget, der kunne tyde på, at sko også kunne gå i arv på tværs af sociale lag. Der er gjort flere fund af typen "salonsko", som var en fransk, outreret skotype med op til $10 \mathrm{~cm}$ høj, slank hæl, beregnet til overklassens fruer og frøkener, når de skulle holde selskab. ${ }^{59}$ Typen var udelukkende beregnet til indendørs brug, men alligevel findes salonsko i affaldet, som er kraftigt mærket af udendørs brug og er blevet brugt til en grænse, der angiveligt ville overskride fine damers standarder for fodtøjets stand. Der ses kraftig slitage på især hæle, som har fået slidt hælflikkerne $^{60}$ samt flere centimeter af hælens trækerne bort og har fået krænget hælens læderbeklædning op, hvilket kun kan forekomme efter flittig udendørs brug på brosten og grusede overflader.

En analyse af skoene viser, at herreskoene var mere slidte end dameskoene, når de hver især blev dømt rede til kassering. Det peger på en kønsmæssig forskel i, hvor grænsen for hvornår en sko skulle træde ud af cirkulation og blive til affald gik.

Af de store mængder af velbevaret tekstil, er et par bukser den eneste intakte beklædningsgenstand, der er bevaret. ${ }^{61}$ De resterende dele var enten slidte, ødelagte handsker, strømper, ærmer, lommeklapper, hatte og klude. Flere af de mange tøjdele viser, at det var normen at reparere. Stoppede strømper forekommer eksempelvist ofte. Men det viser også genbrug i form af beklædning, der er syet af aflagt tekstil. Et eksempel er en barnestrømpe, der er syet sammen af dele af skaftet fra en voksenstrømpe, hvis strømpefod formentlig var blevet for slidt.

Tekstil blev genbrugt i så stor stil, at det til sidst kunne ende som en lille klud, der eksempelvis har været brugt til rengøring eller som "toiletpapir” for overklassen. Ved udgravningen på Esplanaden 50 fandtes talrige klude, og ved en koncentration af små, røde klude viste makrofossilanalyserne $\mathrm{e}^{62}$ af den udtagede jordprøve, at ”jorden” var fækalierig og indeholdt klid, hvilket dyr ikke indtager. Der var med andre ord tale om menneskeafføring og de formodentlig dertilhørende klude fra et lokum.

59 Andersen 2009, s. $98 \mathrm{f}$.

60 Hælflikker er de lag af læder, som har siddet i bunden af hælen og beskyttet trækernen mod slitage.

61 Ringgaard 2010.

62 Makrofossilanalyse er en analyse af rester af større plantedele, fx frø, blade og stængler. 
Personligt affald i form af latrin var også en del af lossepladsens indhold. De arkæologiske udgravninger, især i de mest fugtige lossepladsområder, bringer en særdeles kraftig stank af rådne æg for dagen, når affaldslagene blotlægges. Det velbevarede organiske materiale lugter stadig den dag i dag, når materialet får lov at ilte rigtig for første gang i 300 år. Den kraftige lugt skyldes dels det komposterende, organiske husholdningsaffald og dels indholdet af latrin. Naturvidenskabelige analyser af jordprøver fra udgravningen af lossepladsen under Esplanaden 50 viste et højt indhold af fækalier fra både mennesker og dyr. ${ }^{63}$ De botaniske makrofossilanalyser kan således vise, at det tiltænkte formål med denne losseplads som værende deponi for husholdningsaffald og gadeopfej måske mere var teori end praksis.

Det var ellers hensigten fra bystyret, at latrinen fra mennesker i 1700-tallet skulle ende i de dertil indrettede latringruber eller latrinkasser i de københavnske baggårde. Når gruberne var fyldt op, dækkede man dem til og gravede nye, men de mere velbemidlede kunne også betale sig til løsningen, hvor natmanden kom og tømte latringruben og kørte latrinen på latrinkulen på Christianshavn, som var i funktion fra 1668 til $1779 .{ }^{64}$ Alligevel viste udgravningerne, at latrinaffald endte på lossepladsen i Frederiksstaden, selvom denne ikke skulle være modtager af sådant affald.

Det er også interessant at se på, hvad der ikke endte på lossepladsen. Eksempelvis fandtes ingen møbler. Størrelserne på de fundne stykker af træ fra lossepladsen er da heller ikke større end hælen på en sko. Det må betyde, at møbler blev recirkuleret, og slutteligt brugte man så godt som alt, hvad der skulle kasseres af træ til brændsel, således at disse genstande bogstavelig talt er gået op i røg.

Intet papir fandtes blandt lossepladsens affald, selvom bogbind af læder og træ var bevaret. Det kan skyldes ringe vilkår for bevaring, men kan også være udtryk for, at papiret er blevet genbrugt og til sidst endt som brændsel på samme måde som træet. Ydermere fandtes kun få genstande af metal, trods afsøgning med metaldetektor, da man også må have genbrugt metal i vid udstrækning. Byggeaffald i form af teglsten ses kun i meget begrænsede mængder, idet man også her må have genbrugt stenene som materiale i nybyggeri. Eksempelvis er der ikke noget fundmæssigt, der tyder på, at lossepladsen under Frederiksstaden blev deponi for genbrugeligt byggemateriale efter den omfattende bybrand i 1728 .

Der ses således i fundene et højt niveau af genbrug i 1700-tallet, inden genstanden blev til endeligt affald, både som genbrug af den enkelte genstand ved reparation og modificering og som genanvendelse af materiale, såsom tekstil til papirproduktion, omsmeltning af metal, træ til brænde med videre. Forurening som begreb kendtes ikke i 1700-tallet, men som følge af lossepladsen som en væ- 
sentlig del af affaldskulturen i enevældens København er grundvandet og havet, blevet forurenet med fækalier, bly og rester fra garveri, farverihåndværk m.v. ${ }^{65}$

\section{Lossepladsens udseende}

Ud over den mulige afbildning på Geddes kort over Frederiksstaden fra ca. 1730 findes der tilsyneladende ikke en eneste illustration af lossepladsen under Frederiksstaden fra funktionsperioden. Der skulle ellers synes at være rig lejlighed til at vise affaldet på de mange malerier, kobberstik og tegninger af området og de bygningsværker fra 1600- og 1700-tallet, hvor lossepladsen var nærmeste nabo, men affaldet er ikke afbilledet. Der vises derimod et anonymiseret, stiliseret baggrundssceneri i form af et fladt, tomt landskab undertiden dekoreret med enkelte træer og anden beplantning samt møller, skibe og huse, som ofte er placeret noget kreativt i forhold til motivets perspektiv og orientering.

Fra midten af 1700-tallet findes adskillige malerier og tegninger af Frederiksstaden som en slags registrering og fremvisning af den nye, interessevækkende bydel. Afbildningerne fra perioden skildrer Nykøbenhavn som en ren, nærmest steril, bydel i fuld overensstemmelse med skabernes formål. Fine brolægninger, lige gader, ensartede huse med uniform arkitektur, træer plantet i lige rækker, og intet affald på gaderne. Den del af lossepladsen, der var tilbage, mens Frederiksstaden blev opbygget oven på og ved siden af den, blev ikke foreviget i tidens afbildninger.

Dog findes der et sjældent indblik i en del af skabelsesprocessen af Frederiksstaden, i form af tegninger udført af en søkadet-elev fra kadetakademiet. ${ }^{66}$ Han har i tegnetimen fastholdt et af de få indtryk, man har bevaret fra opførelsen af Amalienborgpalæerne tidligt i 1750'erne, hvor man samtidig får et indtryk af det knap så indbydende fundament til byggepladsen her. Amalienborg bliver bygget på den nedlagte eksercerplads' område, og byggegrunden fremstår som et ujævnt, mudret morads, der må have været et udfordrende fundament for byggeprocessen. At dette sjældne indblik har netop denne afsender, en privatpersons personlige skildring af en detalje fra et område, giver god mening, da kadettens øvelsesskitser ikke havde til formål at blive masseproduceret eller vist offentlig. Det er således kun i den personlige og sjældent bevarede afbildning, at det mere virkelighedstro om end uskønne af området kommer frem. 


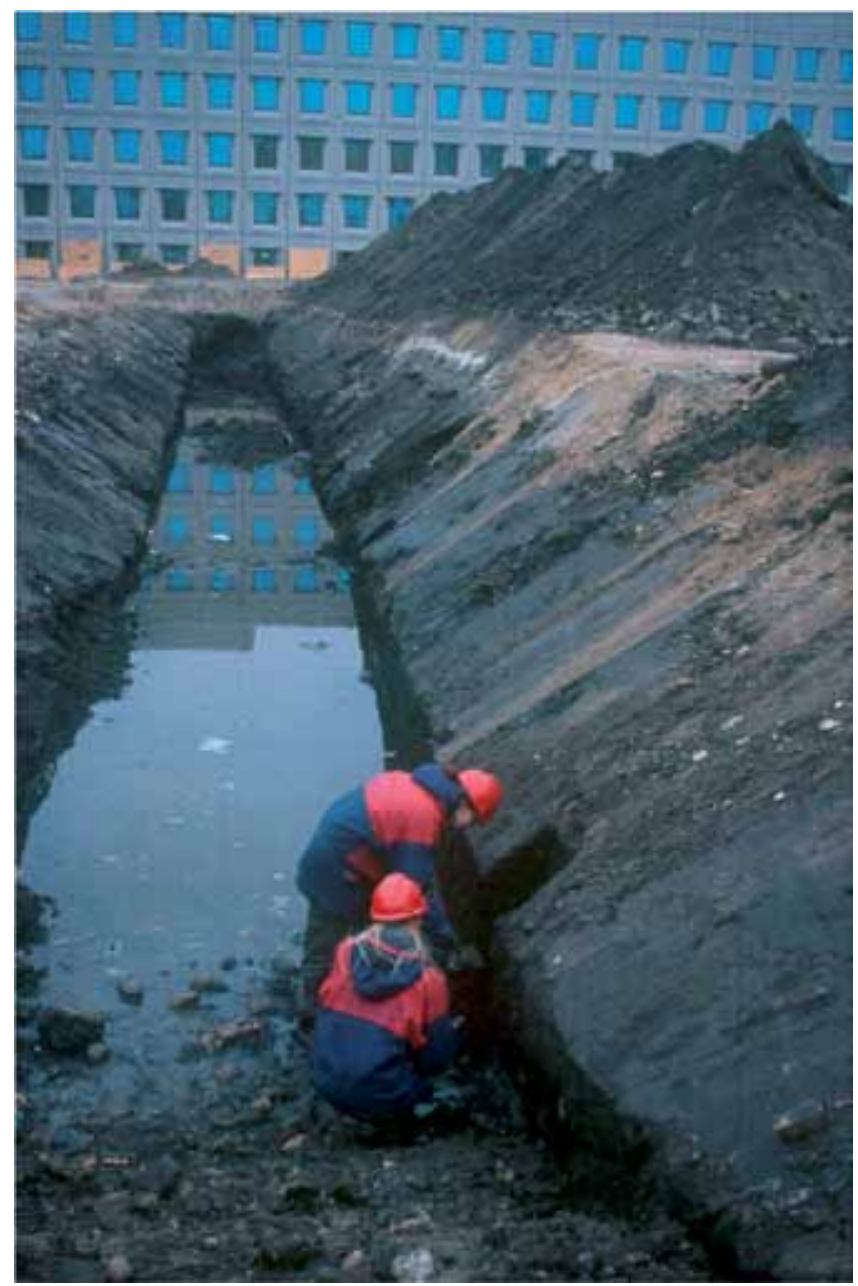

Foto af grøft fra prøveudgravning på grunden Esplanaden 50. De øverste $30 \mathrm{~cm}$ består af moderne stabilgruslag og direkte derunder tre meter affald fra enevælden. Bemærk vandet $i$ bunden af grøften. Det lave vandniveau skyldes grundvandssænkninger i moderne tid. Under enevælden har niveauet været væsentlig højere. Foto: Lene Høst-Madsen, Københavns Museum.

Ved gennemgang af de arkæologiske udgravninger, der er foretaget i Frederiksstaden, optræder meget forskellige oplysninger om affaldets mængde og tilstand alt afhængig af lokaliteten. Under Esplanaden 50 er affaldslagene hele tre meter tykke, mens den vestlige halvdel af Amalienborgpalæerne og slotspladsen har en tykkelse på affaldet på blot ca. $20 \mathrm{~cm}$. Affaldet har udjævnet naturlige fordybninger i landskabet inde på land, mens opfyldninger ved kysten har presset vandet væk og dannet nyt land. De områder af lossepladsen, som var opfyldt langs med og ud i vandet, var tykke og fugtige, mens områderne inde i landet var tynde og mere tørre. Ud fra arkæologiske iagttagelser kan der identificeres et nord-sydgående skel midt gennem Amalienborg Slotsplads. Øst for slotspladsen er lagene tykke og fugtige, mens de vest for slotspladsen er mere sporadiske, smalle og tørre. 
I de skriftlige kilder kan man finde sporadiske oplysninger, som kan bidrage til, hvordan lossepladsen så ud. Tilsyneladende har de enkelte lossepladsområder været markeret med pæle, der har angivet, hvor affaldet måtte læsses af henne, som det eksempelvis blev beskrevet af politimester Johan Bertram Ernst i år 1714, som også er citeret tidligere i artiklen: ”..., tilholdes at udføre deris møg eller andet, som kand tiene til opfyldning, til forskrevne elleve pladtzer og henlegge det, hvor det ved de opstukne pæle og arme vorder anviist,...".67 Der findes også oplysninger, som beskriver adgangs- og aflæsningsforholdene, såsom at vognene ikke kunne komme frem for skidt, og at arealerne var så sumpede, at vognmændenes heste sank i til bugen - flere heste omkom endda. ${ }^{68}$ Man må derfor gå ud fra, at konsistensen af affaldet har været en blød og eftergivelig masse, når der ikke var hård frost. Der bliver i skriftlige kilder nævnt køreramper for netop at kompensere for den bløde masse, for at forhindre mennesker og dyr i at synke i den kviksandslignende masse. ${ }^{69}$ En sådan kørerampe blev fundet ved det arkæologiske tilsyn på Esplanaden $50,{ }^{70}$ og der er tale om en stor tømmerflådelignende konstruktion af planker og stolper, som har fungeret som bro oven på affaldet. Oven på rampen fandtes også affald, hvilket måske er affald, der er faldet af hestevognene, når man tømte vognen. Man har ikke været omhyggelig ved aflæsning af affaldet, og rampen selv endte da også med at blive til affald som en integreret del af lossepladsen, idet de deponerede læs af affald til sidst har usynliggjort rampen. Vi må også formode, at rampen til en vis grad selv er sunket lidt ned i det svampede dynd i takt med det organiske affalds gradvise kompostering og vægten fra oven. At flytte denne overdængede rampe, hvis der har været brug for den andetsteds, har man givetvis ikke gjort. Det har efter al sandsynlighed været lettere at bygge en ny.

Som bydelsfundament har denne eftergivelige masse af affald også sat sine spor i nutidens gadebillede i Frederiksstaden. Adskillige bygninger i Frederiksstaden har siden 1960'erne gennemgået renoveringer af fundamenter, mure og vægge pga. alvorlige sætningsskader. ${ }^{71}$ Det skyldes primært grundvandssænkninger, fordi affaldslagene kollapser i takt med komposteringen af det organiske materiale, hvilket sker, og sker hurtigt, når det organiske affald og de træpæle, som bygningerne tit er funderet med, får tilsat oxygen, hvilket vandet har skånet dem for. ${ }^{72}$ Det er blevet klart for myndigheder og rådgivende ingeniører, at de gamle funderinger er følsomme over for ændringer i miljøet. Grundvandsstanden

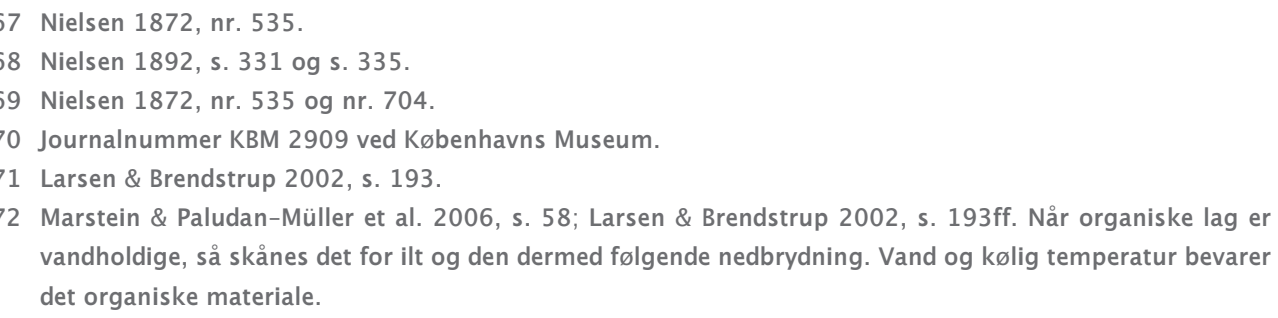
vandholdige, så skånes det for ilt og den dermed følgende nedbrydning. Vand og kølig temperatur bevarer det organiske materiale. 


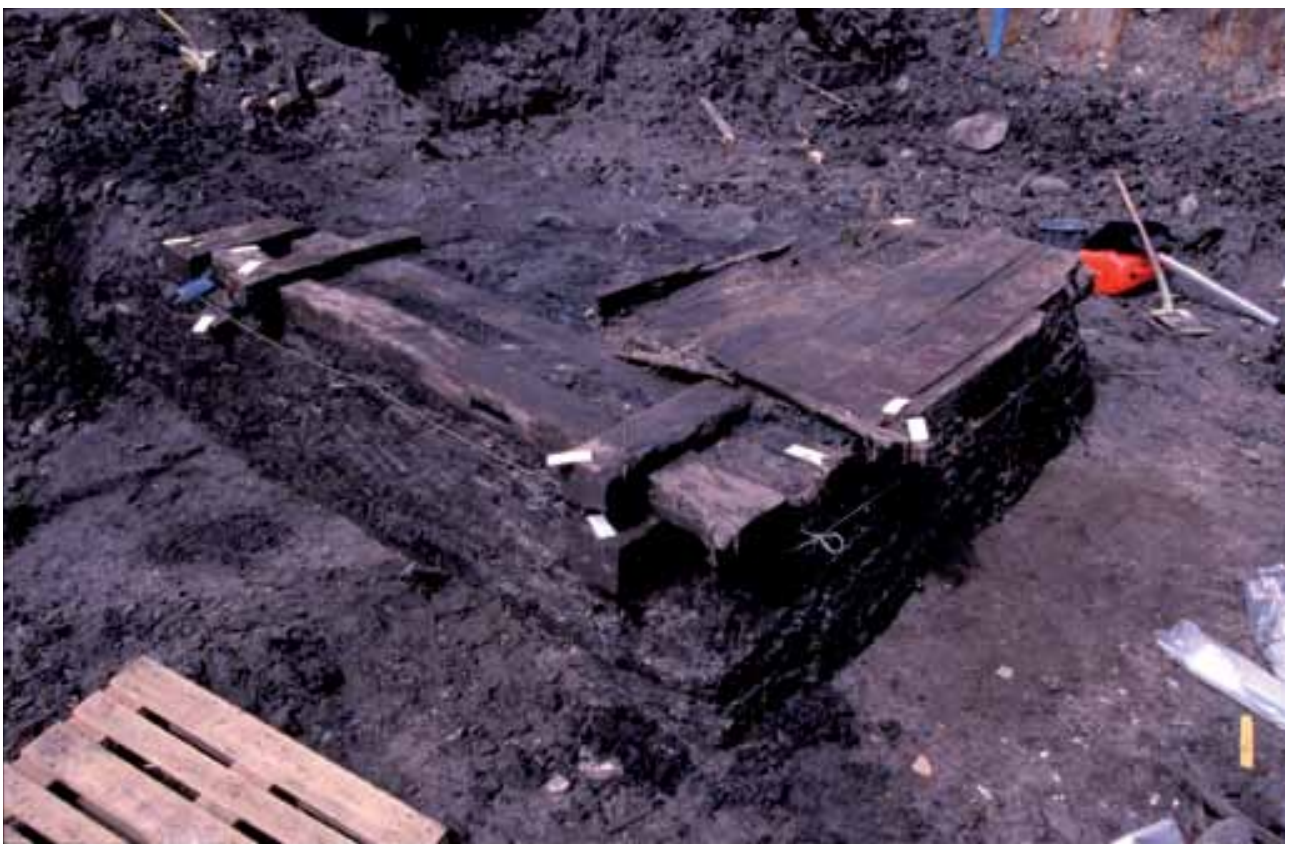

Kørerampe af bjælker og planker under udgravning på Esplanaden 50. Foto: Vivi Lena Andersen, Københavns Museum.

er en af de miljøfaktorer, der påvirkes af nutidig byudvikling, men også vibrationer i jorden forårsaget af moderne trafik. Fundamentets stenpakninger rystes eller skrider ud til siderne, hvis fundamentet har sætningsgivende jord op langs siderne - eksempelvis i form af affaldslag. ${ }^{73}$ En stor del af byens fundamenter er sat på eller gravet ned i sætningsgivende underlag. Lossepladsen som fundament har været stærkt sætningsgivende, hvilket betyder, at de involverede bygninger i de første 10-20 år af deres levetid satte sig med betydelige sætningsskader. ${ }^{74}$ Vi må derfor formode, at Frederiksstadens beboere allerede i sidste halvdel af 1700-tallet oplevede en vis bevægelighed i de nyopførte palæer.

\section{En ny affaldskultur - behov og materialisering}

Med enevælden ændredes Københavns affaldskultur sig kraftigt. Men enevældens system med afhentning af affaldet, så det ikke blev deponeret rundt omkring i byen eller på folks egne matrikler, var en udfordrende og langvarig proces at forankre. Folk ændrede ikke adfærd fra den ene dag til den anden. Affald fra 1700-tallet findes jævnligt ved udgravninger af datidens gårde og gader i centrum af byen, og latrinaffald endte på lossepladsen, selvom denne ikke skulle være 
modtager af sådant affald. Lossepladsen var, ifølge planen og de skriftlige kilder, tiltænkt et afgrænset formål som deponi for husholdningsaffald og gadeopfej, men de arkæologiske fund viser, at dette ikke blev fulgt i praksis, da også latrin fra mennesker blev sendt til byens losseplads.

Selvom formålet var at få affaldet væk fra byens gader, torve, voldgrav og beboelse, forblev affaldet inden for byens mure til brug i den fysiske udvikling af byen, som voksede ud i vandet. Vandets dybde er blevet udnyttet til fulde og har skjult en del af affaldet af vejen samt dannet nyt land. Folk boede, levede og færdedes tæt på de områder, hvor der samtidig har været transport, aflæsning og deponi af affald. Forurening som begreb kendtes ikke i 1700-tallet, men som følge af lossepladsen, som en væsentlig del af affaldskulturen i enevældens København, er grundvandet og havet blevet forurenet. Det er en problematik, som man også globalt set stadig kæmper med i dag på trods af væsentlig bedre indsigt i de miljømæssige konsekvenser.

Datidens genbrugspraksis viser tydeligt, at genbrug af genstande og genanvendelse af materialer forud for endelig kassering ikke er en praksis, som den moderne tids samfund har opfundet, men derimod et meget almindeligt fænomen i enevældens København. ${ }^{75}$ Fundene konstaterer genbrug i stor stil og understøtter konkret øvrige kilders udsagn om en hyppig genbrugspraksis forud for kassering.

Hvad angår lossepladsens udseende, så viste de kilder, som man umiddelbart formoder, skulle være de mest oplagte til at tegne et fysisk billede af en urban lokalitet, det værende kartografien og billedkunsten, sig ikke at være egnede i dette tilfælde. I dette ligger et mentalitetshistorisk aspekt, hvor man enten ikke ville skildre det eller slet ikke tænkte på at skildre det. Det kunne ved anden lejlighed være interessant at se nærmere på de elementer i byrummet, som ikke har efterladt sig visuelle spor i kartografien og billedkunsten samt den bagvedliggende mentalitetshistorie.

Arkæologien og de skriftlige kilder kan sammen beskrive lossepladsen som værende meget varieret i omfang (fra ca. $20 \mathrm{~cm}$ til 3 meter i tykkelse), uskarp i afgrænsning ind mod land, men skarpt afgrænset mod kysten (hvor bolværker dannede væg for affaldet), sumpet med kritisable adgangs- og aflæsningsforhold (som ramper af træ skulle kompensere for) og med det væsentlige formål at opfylde naturlige huller og udjævne terrænet, så en ny bydel sidenhen kunne rejse sig. En bydel, hvis bygninger formentlig allerede få årtier efter opførelse, såvel som i dag, måtte bøde for det organiske og bevægelige fundament af affald i form af sætningsrevner.

Behovet for et centralt styret system for bortskaffelse af affald er ikke et nyt fænomen, og lossepladsen under Frederiksstaden, som her er i fokus, har angive- 
ligt ifølge de historiske kilder og arkæologien haft sin begyndelse i sidste halvdel af 1600-tallet.

De forskellige kilder har alle sine styrker, forskelle, variationer og svagheder. Dette gælder også for spørgsmålet om, hvornår behovet for lossepladsen under Frederiksstaden opstod og den dertilhørende funktionsperiode. Eksempelvis viser Geddes kort fra 1761, at et område blev brugt som Botanisk Have, mens de arkæologiske fund og deres datering viser, at området stadig aktivt blev benyttet som losseplads på samme tidspunkt. Arkæologien og garbologien har med andre ord bidraget med noget, vi ikke kunne vide i forvejen.

Så længe mennesker lever i små grupper og med levevis som nomader, er affald forholdsvist uproblematisk, og generne er begrænsede. Udviklingen inden for bofasthed, det nye system af matrikuleringer, specialiserede byerhverv og koncentrationen af tusindvis af mennesker inden for samme byrum førte til en proportionel stigning i affaldsmængden inden for et geografisk, begrænset område med dertilhørende gener, sygdomsfrygt og vanskeliggørelse af hensyn til hverandre til følge. Styret måtte skride til handling og udnytte de neutrale, urbane rum til deponi for stadens urenlighed. Et element af den københavnske løsning på dette affaldsproblem materialiserede sig i form af den nu identificerede losseplads under det nuværende Frederiksstaden.

Med denne undersøgelse er fokus for en stund flyttet fra det kendte til det skjulte, og dette kan nuancere et områdes historie og måske bidrage til nye vinkler og tilgange i måden at tolke aspekter af denne historie på. Dette ansporer tværfaglige projekter med forskere, som med hver deres ekspertise behørigt kan behandle og studere de respektive kilder og give flere facetter til affaldsstudier samt yderligere indsigt i en fundamental, men ofte negligeret, urban lokalitet, som en losseplads er. En losseplads er ikke blot en endestation for uønskede objekter, men den er også en social afspejling af det samfund, som har produceret den. I lossepladsen er alle samfundslag ofte repræsenteret. Lige så adskilte disse mennesker kunne være i det levede liv, opdelt af sociale skel såvel som matrikulære skel, lige så sammenfiltrede kunne deres efterladenskaber være i affaldets efterliv på lossepladsen, hvor alle disse mange objekter blev til én samlet masse og til én betegnelse: Affald. Studier af affaldet med et socialt perspektiv vil således være et vedkommende bidrag til den ellers kendte historie om enevældens samfund.

\section{Litteratur}

Andersen, Vivi Lena 2006: "Esplanaden versus Amager Strandpark. Kampen for nyere tids arkæologi i Danmark”. Henriette Lyngstrøm et al. (red.): Fra Vandkunsten til Vestpynten af Amager. 20 arkæologiske essays. Saxo-instituttet, Københavns Universitet, s. 111-115. 
Andersen, Vivi Lena 2009: "På fod med nyere tids arkæologi - sko som kilde”. Henriette Lyngstrøm (red.): Specialer ved Forhistorisk Arkæologi 2006, 2007 og 2008. Saxo-instituttet, Københavns Universitet, s. 93-102.

Andersen, Vivi Lena og Annine Moltsen 2008: "The dyer and the Cook: Finds from 8 Pilestræde, Copenhagen, Denmark. Post-Medieval Archaeology 41:2, s. 242-263.

Andrén, Anders 1997: Mellan ting och text. En introduktion till de historiska arkeologierna. Stockholm.

Bitter, Peter 2011: "Into the pit? Waste management and cesspit finds in Alkmaar”. Hemmy Clevis (ed.): Assembled Articles IV. Zwolle.

Bobé, Louis 1889: Operahusets Brandpaa Amalienborg den 19de April 1689. København.

Branton, Nicole 2009: "Landscape Approaches in Historical Archaeology: The Archaeology of Places”. Teresita Majewski og David Gaimster (red.) International Handbook of Historical Archaeology. New York, s. 51-65.

Bregnsbo, Michael 2009: “Copenhagen - The Capital of an Empire”. Søren Bitsch Christensen og Jørgen Mikkelsen (red.): Danish Towns during Absolutism. Urbanisation and Urban Life 1600-1848. Dansk Center for Byhistorie, s. 133-152.

Dahl, Bjørn Westerbeek 1991: Gamle københavnske bykort og prospekter - gennem 800 år. København.

Dahl, Bjørn Westerbeek 2002: Geddes eleverede kort over København 1761. Bergiafonden.

Damsholt, Tine, Camilla Mordhorst og Dorte Gert Simonsen (red.) 2009: Materialiseringer. Nye perspektiver på materialitet og kulturanalyse. Aarhus Universitetsforlag.

Deetz, James 1996 (1977): In Small Things Forgotten. An Archaeology of Early American Life. New York.

Douglas, Mary 2006 (1966): Purity and Danger. London/New York.

Egan, Geoff 2005: Material Culture in London in an Age of Transition: Tudor and Stuart Period Finds c 1450-c 1700 from Excavation at Riverside Sites in Southwark. Museum of London Archaeology Service.

Elling, Christian og Victor Hermansen 1932: Holbergtidens København: i billeder fra samtiden. København.

El-Sharnouby, Hoda og Lene Høst-Madsen 2008: "København - fra fiskerleje til middelalderlig købstad”. Hans Andersson et al (red.): De første 200 årene nytt blikk på 27 skandinaviske middelalderbyer. Universitetet i Bergen Arkeologiske Skrifter, s. 147-155.

Eriksen, John M. 1996: Lossepladser og opfyldning i København. Historisk redegørelse for Københavns opfyldninger og lossepladser fra omkring århundredskiftet til 1995. Miljøkontrollen, Københavns Kommune. 
Eriksen, Flemming S. og John M. Eriksen 2002: ”Arkivundersøgelser”. John Frederiksen et al. (red.): Ingeniørgeologiske forhold i København. Dansk Geoteknisk Forening, s. 229-237.

Faber, Tobias 1989: København før og nu - og aldrig: Frederiksstaden og Nyhavn. Fogtdal.

Generalstabens topografiske Afdeling 1877: Ledetraad i Detailmaalingen.

Gräslund, Bo 1996: Arkeologisk Datering. Lund.

Hawkins, Gay og Stephen Muecke 2003 (red.): Culture and Waste. The Creation and Destruction of Value.

Henningsen, Peter 2009: "Copenhagen poor relief and the problem of poverty, ca. 1500-1800”. Søren Bitsch Christensen og Jørgen Mikkelsen (red.): Danish Towns during Absolutism. Urbanisation and Urban Life 1600-1848. Dansk Center for Byhistorie, s. 325-330.

Hilden, Hans Peter 1973: Skrald, storby og miljø. En beretning om Københavns kamp mod affaldet gennem 200 år. Renholdningsselskabet af 1898.

Høst-Madsen, Lene og Rikke Søndergaard Kristensen 2005: ”Lossepladsen sladrer. Industriel arkæologi i København”. Fabrik og Bolig 2005, s. 41-53.

Høst-Madsen, Lene og Henrik Harnow 2012: "Historical Archaeology and Archaeological Practice in Denmark". Henrik Harnow et al. (red.): Across the North Sea. Later Historical Archaeology in Britain and Denmark, c. 1500-2000 $A D$. University Press of Southern Denmark.

Jörpeland, Lena Beronius 2001: ”Den grå vardagen - städning och renhållning i den medeltida staden". Bebyggelseshistorisk tidsskrift, Medeltidsstadens arkeologi Nr. 42, 2001.

Korsgaard, Peter 2006: Kort som kilde. Dansk Historisk Fællesråd.

Lanzky, Vibeke F. Og Camilla Olsen 1999: Nedbrydning af organiske stoffer under Grinsted Gl. Losseplads. Danmarks Tekniske Universitet.

Larsen, Jørgen og Jens Brendstrup 2002: ”Oversigt over historiske funderingsmetoder". John Frederiksen et al. (red.): Ingeniørgeologiske forhold i København. Dansk Geoteknisk Forening, s. 193-204.

Marstein, Nils og Carsten Paludan-Müller (red.) 2006: The Monitoring manual Procedures \& Guidelines for the Monitoring, Recording and Preservation/Management of Urban Archaeological Deposits. Riksantikvaren og Norsk Institutt for kulturminneforskning.

Moreland, John 2001: Archaeology and Text. London.

Nielsen, Oluf 1872: Kjøbenhavns Diplomatarium VIII. København.

Nielsen, Oluf 1892: Kjøbenhavns Historie og Beskrivelse VI. Kjøbenhavn under Kong Frederik den Fjerde (1699-1730). København.

Oswald, Adrian 1975: Clay Pipes for the Archaeologist. British Achaeological Reports BS 14. 
Pade, Dorte Moon og Eskild Thulani Paamand 2008: Afværge af gasspredning fra gammel losseplads. Danmarks Tekniske Universitet.

Panduro, Poul og Sten Thorsen 2000: ”Dybdekomprimering af losseplads”. Dansk Vejtidsskrift s. 55-57.

Pedersen, Gitte Bukh 2004: Sengeløse Losseplads. Evaluering af toplag på lossepladser. Miljø \& Ressourcer. Danmarks Tekniske Universitet.

Rahbek, Knud Lyne \& Christen Henriksen Pram 1794: Ny Minerva, bind 37.

Rasmussen, Ulla Fraes 2005: "Havneforhold og bolværker i Køge”. Thomas Roland (red.): Bolværker - fra middelalderen og nyere tid. Næstved Museum.

Rathje, William Laurens 1981: A Manifesto for modern Material-Culture Studies. Richard Gould \& Michael Schiffer (red.) 1981: Modern Material Culture: The Archaeology of Us. New York, s. 51-57.

Rathje, William Laurens og Cullen Murphy 1992. Rubbish: The Archaeology of Garbage. New York.

Schiffer, Michael 1972: Archaeological context and Systemic context. American Antiquity. 37:2.

Schiffer, Michael; Theodore E. Downing og Michael McCarthy 1981: Waste Not, Want Not: An Ethnoarchaeological Study of Reuse in Tucson, Arizona. I: Gould, R. og M. Schiffer (red.) 1981: Modern Material Culture: The Archaeology of Us. New York, s. 67-86.

Seasholes, Nancy 2003: Gaining Ground. A History of Landmaking in Boston. Massachusetts.

Skriver, Peter 2008: Bykortet som sprog. Om kortet som kilde og formidling. I: Byerne og den byhistoriske kartografi. Dansk Center for Byhistorie. Skrifter om dansk byhistorie, bind 5, nr. 60, s. 9-24.

Stadsingeniørens Direktorat 1947: København fra bispetid til borgertid. Byplanmæssig udvikling til 1840. København.

Thompson, Michael 1979: Rubbish Theory. Oxford.

Wiene, Inger 2013 (in prep.): "Kiøbenhavns Folk plages tit af skidne Gader”. Historiske Meddelelser om København. Selskabet for Københavns Historie.

Wolfram, Sabine (red.) 2003: MÜLL: Facetten von der Steinzeit bis zum Gelben Sack. Begleitschrift zur Sonderausstellung vom 06. September bis 30, November 2003 in Oldenburg anschliessend in Hanau, Mainz am Rhein.

\section{Utrykte kilder}

Andersen, Vivi Lena 2004: Udgravningsberetning for den arkæologiske prøveundersøgelse: KBM 2897 Pilestræde nr. 8, matr.nr. 105, Købmager Kvarter, Københavns Sogn, Sokkelund Herred, Københavns Amt. Rapport ved Københavns Museums antikvariske enhed. 
Andersen, Vivi Lena 2007: SKO fra 1700-talslossepladsen på Esplanaden 50, København. En vurdering af nyere tids arkæologi. Speciale fra Forhistorisk Arkæologi, Saxo Instituttet, Københavns Universitet.

Dahl, Bjørn Westerbeek 2006: Notat om Sankt Annæ Øster Kvarter nr. 400 og områdets ældre historie. Rapport ved Københavns Museums Antikvariske enhed.

Enghoff, Inge Bødker 2004: Rapport over analyser af knoglemateriale fra Mærskgrunden, Esplanaden, København, ZMK 30/2003, KBM 2307. Statens Naturhistoriske Museum, Zoologisk Museum.

Høst-Madsen, Lene 2003: Beretning for den arkæologiske prøvegravning af KBM 2307 Mærsk Hovedsæde. Rapport ved Københavns Museums Antikvariske enhed.

Jensen, Jane Jark 2006: Udgravningsberetning for Bremerholm II, KBM 3220. Øster Kvarter, Københavns Sogn, Sokkelund Herred, Københavns Amt. Rapport ved Københavns Museums Antikvariske enhed.

Kristensen, Rikke Søndergaard 2004: KBM 2307 Hovedudgravning. Sammenfatning af fajance, porcelæn, lertøj, stentøj, glas og kridtpiber. Rapport ved Københavns Museums Antikvariske enhed.

Mikkelsen, Anita 1991: Skarn, Skrald og Affald. Træk af affaldets kulturhistorie. 1840-1990. Speciale ved Europæisk Etnologi, Københavns Universitet.

Moltsen, Annine 2003: Lag- og makrofossilanalyser fra Mærsk (KBM 2307) NOK rapport nr. 31-2008. Natur \& Kultur. Rapport ved Københavns Museums antikvariske enhed.

Ringgaard, Maj 2010: "To par strixstrømper oc en nattrøie naccarat”, filtede og strikkede tekstiler fra omkring 1700 fundet $i$ Københavnske byudgravninger - og sammenhænge mellem tekstilers farve og bevaring. Ph.d.-afhandling, Københavns Universitet. 


\section{The uncleanliness of landfill culture in 18th-century Copenhagen}

After the discovery of an 18th-century landfill that contained a diversity of wellpreserved objects discarded by Copenhageners, about 30 archaeological surveys have since been conducted at a site in the north-central part of the city. This coastal district, called Frederiksstaden, is now known for its prominent mansions and the home of the Danish royal family, but its function as a landfill is rarely mentioned as a phenomenon in stories about the area. From studying the excavated items, this article seeks to explore how they reflect the trash culture during Copenhagen's Age of Absolutism, as well as to describe the landfill's appearance and when the need for it arose.

Using the archaeological source material as a base, the study also examined geotechnical, written, cartographic, iconographic and natural-scientific sources in order to achieve a more nuanced understanding of the landfill and to reflect on how the different sources relate to each other. This article argues that getting citizens to adapt to the new system of trash management was a long and challenging process; e.g., according to written sources, the landfill was only supposed to receive household garbage and sweepings from the city's streets, but the archaeological evidence shows that human waste from latrines was also disposed of there. Other trash items found in the landfill exhibit signs of extensive reuse before having been discarded, which supports statements from other sources.

The most obvious sources for information about the appearance of the landfill - specifically, 18th-century cartography and art - proved not to be worthwhile. Instead, archaeological evidence and written sources provided a better image of the swampy conditions that caused the terrain to even out over time - a process that began in this area during the second half of the 17th century. The need for a centrally-controlled framework to manage garbage seems to be connected to the development of a permanent settlement, the new system of matriculation, an emphasis on ownership and overall population growth, which included the fear and nuisance of disease. This resulted in using a coastal area as a landfill - an area where aristocratic mansions were also built during Copenhagen's Age of Absolutism. 